\title{
ARTICLE
}

\author{
Gerry W. Beyer
}

\section{Avoid Being a Defendant: Estate Planning Malpractice and Ethical Concerns}

\begin{abstract}
An estate planner may become a defendant in a case involving an estate he or she planned in two main ways. First, the attorney may have performed his or her services in a negligent manner potentially creating exposure to malpractice liability. Second, the attorney's conduct may have lapsed below ethically acceptable standards.

This Article reviews the exposure an estate planner may have to malpractice liability with emphasis on Texas law and then focuses the reader's attention on ethical issues that may arise while preparing or executing the plan. The author hopes that by pointing out potentially troublesome areas, the reader will avoid the ramifications of drafting a flawed estate plan or having a lapse of ethical good judgment which may lead to the frustration of the client's intent, financial loss to the client or the beneficiaries, personal embarrassment, and possible disciplinary action.
\end{abstract}

Author. Governor Preston E. Smith Regents Professor of Law, Texas Tech University School of Law. B.A., Eastern Michigan University; J.D., Ohio State University; LL.M. \& J.S.D., University of Illinois. The author thanks Brooke Dacus, 2015 J.D. Candidate, Texas Tech University School of Law, for her excellent assistance in the preparation of this Article. Much of this Article is derived from Professor Beyer's previous CLE material. 


\section{ARTICLE CONTENTS}

I. Introduction .......................... 228

II. The Potential of Malpractice Liability for Negligent

Estate Planning . ............................ 229

A. Disgruntled or Omitted Beneficiary as Plaintiff. 229

1. The Privity Wall Is Erected .............. 229

2. The Privity Wall Begins to Crack........... 230

3. Current Status of the Privity Wall ......... 231

B. Personal Representative of the Estate as Plaintiff 233

III. Potentially Negligent Conduct ............... 235

A. Poor Client Interactions ................. 235

1. Failure to Gather Sufficient Information .... 235

2. Believing Client Without Independent Verification......................... 235

3. Neglecting Communications with Client.... 236

4. Failure to Act Timely................. 237

5. Failure to Document Unusual Requests and Recognize Situations Leading to a Will Contest ............................. 237

B. Errors in Will Drafting ................. 238

1. Poor Proofreading of Documents.......... 238

2. No Specific Provision Regarding Ademption and Lapse ........................... 238

3. Including Payment of "Just Debts" Provision ............................ 239

4. Failure to Discuss Exoneration and Abatement. .......................... 239

5. Failure to Extend Survival Period ........... 240

6. Failure to Address Tax Apportionment...... 240

7. Failure to Address Pretermitted, Adopted, and Non-marital Children ................ 241 
8. Inadequate Incorporation by Reference. . . . 242

9. Failure to Externally and Internally Integrate

Testamentary Documents............... 242

10.Imprecise Use of Language. .............. . 243

11.Inadvertent Creation of Election Will....... 244

12.Violation of Rule Against Perpetuities. . . . . . 244

13.Inadequate Tax Planning ............... 244

14. Failure to Provide for Independent Administration. ....................... 245

15.Lack of Provisions Regarding Personal

Representative ........................ 245

C. Improper Will Execution ................. 246

1. Ceremony Procedure ................. 246

2. The Testator's Signature ................ 247

3. Lack of Sufficient Witnesses................ 248

4. Improperly Completed Self-Proving Affidavit. ........................... 248

5. Execution of Duplicate Originals . . . . . . . . . 249

D. Errors in Trust Drafting ................... 249

1. Failure to Address Principal and Income

Issues ............................ 249

2. Omission of Spendthrift Provision......... 250

3. Misstating Ability to Revoke ............ 250

E. Other Troublesome Mistakes ............. 250

1. Improper Document Preservation .......... 250

2. Failure to Provide Client with Sufficient Post-estate Plan Instructions. . . . . . . . . . . 251

3. Failure to Use Disclaimers Where Appropriate........................ 252

4. Failure to Plan for Disability and Death..... 252

IV. Potential Exposure for Breaches of Professional Responsibility........................... 253 
A. Estate Planning for Both Spouses............. 253

1. Models of Representation for Married

Couples ............................ 254

a. Family Representation .............. . 254

b. Joint Representation .................. 254

c. Separate Concurrent Representation of Both Spouses. ...................... 255

d. Separate Representation.............. 256

2. Dangers of Joint Representation ........... 256

a. Creates Conflicts of Interest . . . . . . . . . 256

b. Accommodating the Modern Family ..... 256

c. Bias Toward Spouse If Past Relationship with Attorney Exists . . . . . . . . . . . . . . 257

d. Opposing Objectives Between Spouses . . . 257

e. Power Struggle Between Spouses..... . . . 258

f. A Faltering Marriage.................. 258

g. Unbalanced Estate Assets Between Spouses............................ 259

h. Forces Release of Confidentiality and Evidentiary Privileges ................. . 259

i. Discourages Revelation of Pertinent Information. . . . . . . . . . . . . . . . . 260

j. Increases Potential of Attorney Withdrawal ..................... 260

k. Creates Conflicts Determining When Representation Is Completed ............ 261

3. Recommendations .................. 261

a. Representation of Only One Spouse. . . . . 262

b. Joint Representation of Both Spouses. . . . 262

B. Representation of Non-spousal Relatives ....... 265

C. Naming Drafting Attorney, Attorney's Relative, or Attorney's Employee as a Beneficiary ....... . 265 
1. Effect on Validity of Gift ............. 265

2. Effect on Ethical Duties ............... 266

D. Naming Drafting Attorney as a Fiduciary ..... 267

E. Naming Drafting Attorney as Fiduciary's Attorney ............................ 268

F. Fiduciary Hiring Self as Attorney ............. 268

G. Attorney as Document Custodian ............ 269

H. Capacity of Representation ............... 270

V. Conclusion ......................... 272

Appendix............................ 273

\section{INTRODUCTION}

\section{"This thorn in my side is from the tree I've planted."}

All it takes is one careless act to place you in the hot seat for months or years where you might watch your personal, professional, and financial life crumble around you.

An estate planner may become a defendant in a case involving a planned estate in two main ways. First, the attorney may have performed services in a negligent manner, potentially creating exposure to malpractice liability. A recent study revealed that $10.67 \%$ of malpractice claims are based on conduct relating to estate, trust, and probate. ${ }^{2}$ Second, the attorney's conduct may have lapsed below ethically acceptable standards.

This Article reviews the exposure an estate planner may have to malpractice liability and then focuses the reader's attention on ethical issues that may arise while preparing or executing the plan. I hope that by pointing out potentially troublesome areas, the reader will avoid the ramifications of drafting a flawed estate plan or having a lapse of ethical good judgment, which may lead to the frustration of the client's intent, financial loss to the client or the beneficiaries, personal embarrassment,

1. Metallica, BleEding Me (Elektra Records 1996).

2. See James Podgers, Dubious Honor, in Your ABA, A.B.A. J., Dec. 2012, at 58, 58 (listing estate, trust, and probate as one of the leading areas for legal malpractice). 
and possible disciplinary action.

\section{The Potential of Malpractice Liability for Negligent Estate PLANNING}

\section{A. Disgruntled or Omitted Beneficiary as Plaintiff 3}

\section{The Privity Wall Is Erected}

Because estate planning requires an especially high degree of competence, the potential malpractice liability of an estate planning attorney for negligence is great. ${ }^{4}$ Estate planning requires a thorough knowledge of many areas of the law, such as: wills, probate, trusts, taxation, insurance, property, and domestic relations. As one commentator has stated, "Any lawyer who is not aware of the pitfalls in probate practice has been leading a Rip Van Winkle existence for the last twenty years." 5

When discovery of errors with the will or the will execution ceremony occurs during the testator's lifetime, the testator's only loss is the cost of having another will prepared and executed (unless, of course, tax or other benefits have been permanently lost). This is normally not the type of situation where malpractice liability litigation will arise. The attorney may be able to avoid becoming a defendant by simply having the will reexecuted without cost to the client and providing appropriate apologies for the inconvenience.

The problem is that errors usually do not manifest themselves until after the client's death. At this time, the testator's estate could probably sue the negligent attorney. However, the only damages would be the attorney's fees paid for drafting the will since there would be no other diminution of the estate funds caused by the error. Accordingly, if there is a flaw in the will or the will execution ceremony causing the will to be ineffective and

3. Portions of this section are adapted from GERRY W. BEYER, TEXAS PraCticE: TEXAS LAW OF WILls $\$ \$ 53.1, .10$ (3d ed. 2002). See Gerry W. Beyer, Avoiding the Estate Planning "Blue Screen of Death"-Common Non-tax Errors and How to Prevent Them, 1 EST. PLAN. \& CMTY. PROP. L.J. 61, 64 (2009).

4. See David Becker, Broad Perspective in the Development of a Flexible Estate Plan, 63 IOWA L. REV. 751, 759 (1978) ("[C]omparatively few lawyers recognize the expertise and particular talents essential to estate planning.").

5. Robert E. Dahl, An Ounce of Prevention-Knowing the Impact of Legal Malpractice in the Preparation and Probate of Wills, DOCKET CALL, Summer 1981, at 9, 9. 
that flaw can be traced to the conduct of the attorney in charge, it is the intended beneficiaries who now find themselves short-changed that are apt to bring a malpractice action.

Traditionally, attorneys did not have to fear actions by these injured beneficiaries because they could successfully raise the defense of lack of privity. The general rule was that the attorney did not owe a duty to an intended beneficiary, a non-client, because there was no privity between the attorney and the beneficiary. However, the view that these beneficiaries may proceed with their actions against the drafting attorney despite the lack of privity has replaced this strict privity approach.

\section{The Privity Wall Begins to Crack}

In 1958, the Supreme Court of California overruled the strict privity requirement in Biakanja $v$. Irving, ${ }^{6}$ a case involving a notary public. ${ }^{7}$ The plaintiff received only a one-eighth intestate share of the decedent's estate rather than the entire estate because the attestation of the will was improper. ${ }^{8}$ The court rejected the body of common law requiring privity and determined that the imposition of a duty to third persons is a matter of policy and involves the balancing of six factors:

1) the extent to which the transaction was intended to affect the plaintiff;

2) the foreseeability of harm to the plaintiff;

3) the degree of certainty that the plaintiff suffered injury;

4) the closeness of the connection between the defendant's conduct and the injury suffered;

5) the moral blame attached to the defendant's conduct; and

6) the policy of preventing future harm.?

The court concluded that the "[d]efendant must have been aware from the terms of the will itself that ... [the] plaintiff would suffer the very loss [that] occurred" if faulty solemnization caused the will to be invalid. ${ }^{10}$ The court stated that such conduct needed to be discouraged and not protected by immunity from civil liability as would have been the case if this plaintiff, the only person who suffered a loss, were denied a valid cause of action. ${ }^{11}$ Accordingly, the court held the notary liable "for the

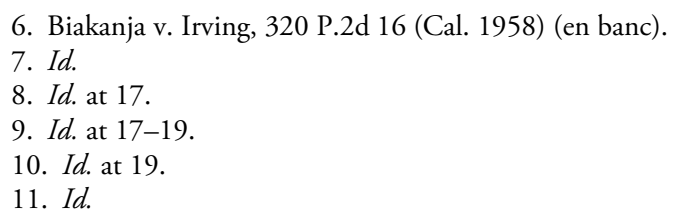


difference between the amount [that the intended beneficiary] would have received had the will been valid" and the intestate share. ${ }^{12}$

Less than four years later, the California Supreme Court repeated essentially the same principle in Lucas $v$. Hamm. ${ }^{13}$ The court held that an attorney's liability for preparing a will could extend to the intended beneficiary. ${ }^{14}$ The court reasoned:

$[\mathrm{O}]$ ne of the main purposes which the transaction between defendant and the testator intended to accomplish was to provide for the transfer of property to plaintiffs; the damage to plaintiffs in the event of invalidity of the bequest was clearly foreseeable; it became certain, upon death of the testator without change of the will, that plaintiffs would have received the intended benefits but for the asserted negligence of defendant; and if persons such as plaintiffs are not permitted to recover for the loss resulting from negligence of the draftsman, no one would be able to do so, and the policy of preventing future harm would be impaired. ${ }^{15}$

Most jurisdictions have followed these California cases and have held attorneys liable to the intended beneficiaries. There are now fewer than ten states remaining that have retained the privity requirement in estate planning cases. ${ }^{16}$

\section{Current Status of the Privity Wall}

As discussed above, the privity doctrine allowed only clients to bring a legal malpractice action against attorneys in estate planning cases. ${ }^{17}$ As many courts began to relax the privity wall to allow beneficiaries to bring a malpractice claim, states adopted one of three approaches to legal malpractice in estate planning cases: (1) the broad cause of action; (2) the "Florida-Iowa" rule; and (3) the strict privity approach. ${ }^{18}$

12. Id. at 17.

13. Lucas v. Hamm, 364 P.2d 685 (Cal. 1961) (en banc).

14. Id. at 689 .

15. Id. at 688. The court eventually held that the attorney was not negligent for failing to master a rule against perpetuities problem. Id. at 690-91.

16. See Martin D. Begleiter, The Gambler Breaks Even: Legal Malpractice in Complicated Estate Planning Cases, 20 GA. ST. U. L. REV. 277, 281-82 (2003) (discussing how the number of states that maintain a strict privity rule for estate planning has dwindled to nine since 1962).

17. See Bradley E.S. Fogel, Estate Planning Malpractice: Special Issues in Need of Special Care, PROB. \& PROP., July-Aug. 2003, at 20, 20 (describing the history of the privity doctrine as one in which only clients could bring claims against estate planning attorneys despite the fact that it is the intended beneficiaries who are usually harmed).

18. See id. (categorizing the three approaches states have addressed malpractice in estate planning). 
States following the broad cause of action approach determine whether a beneficiary can bring a malpractice claim against an estate planning attorney by applying a multi-factor balancing test; ${ }^{19}$ thus, the broad cause of action approach is also known as the balancing factors test. These factors are typically like those enumerated above from the Biakanja case. ${ }^{20}$

The Florida-Iowa rule is a narrower cause of action compared to the broad cause of action. ${ }^{21}$ States following the Florida-Iowa rule allow a beneficiary to maintain a malpractice claim "against the estate planning attorney only if the client's" will (as expressed in the will) is frustrated; thus, the malpractice must "be apparent on the face of the will." 22

Lastly, some courts retain the strict privity rule so that the lack of privity "between the estate planning attorney and the beneficiaries is an absolute bar to legal malpractice claims." 23

Some states do not adopt these three approaches strictly, but will have a "relaxed privity" approach. The relaxed privity approach generally requires privity, but with exceptions in certain circumstances (the exceptions vary from state to state).

These approaches have been adopted by various states. Although Hawaii and Montana are unclear as to whether privity is required, other states use the aforementioned rules to elucidate the privity requirement. States using the balancing factors approach generally do not require privity. ${ }^{24}$ However, in states where privity is required, courts undertake either a relaxed $^{25}$ or strict ${ }^{26}$ privity approach or the Florida-Iowa approach. ${ }^{27}$ Contrastingly, Oregon, Montana and Hawaii are states that

19. See id. (restating the reasoning of the California Supreme Court using a multi-factor balancing test to allow malpractice claims despite lack of privity).

20. See Biakanja v. Irving, 320 P.2d 16, 19 (Cal. 1958) (en banc) (listing the factors the California Supreme Court considered when determining whether an estate planner could be liable to a third party in the absence of privity).

21. See Fogel, supra note 17, at 22 (expressing how states that were dissatisfied with the broad cause of action approach adopted the narrower Florida-Iowa rule).

22. Id. at 20 .

23. Id.

24. See infra Appended Table. These states include Arizona, California, Missouri, Nevada, New Mexico, North Carolina, Rhode Island, Washington, and Wyoming.

25. See infra Appended Table. Arkansas, Connecticut, District of Columbia, Florida, Georgia, Illinois, Indiana, Kansas, Louisiana, Maryland, Massachusetts, Maine, New Hampshire, Oklahoma, Pennsylvania, South Dakota, Tennessee, Vermont, Virginia, Washington, West Virginia, and Wisconsin.

26. See infra Appended Table. Alabama, Alaska, Maine, Nebraska, Ohio, Texas, and Utah.

27. See infra Appended Table. Idaho, Iowa, and Michigan. 
address estate planning malpractice on a case-by-case basis. ${ }^{28}$

\section{B. Personal Representative of the Estate as Plaintiff}

When a personal representative brings an action against the drafting attorney for malpractice, the privity shield is of no defensive value because the client was in privity with the attorney and the personal representative is merely stepping into the client's position. The leading case demonstrating this principle is Belt v. Oppenheimer, Blend, Harrison \& Tate, Inc. ${ }^{29}$ a 2006 Supreme Court of Texas case in which the executors sued the attorneys who prepared the testator's will asserting that the attorneys provided negligent advice and drafting services. ${ }^{30}$ The executors believed that the testator's estate incurred over $\$ 1.5$ million in unnecessary federal estate taxes because of the malpractice. ${ }^{31}$ The briefs reveal that the main problem was that the testator did not form a family limited partnership or take other steps that could have led to a lowering of the estate's value.

Both the trial and appellate courts agreed that the executors had no standing to pursue the claim because of lack of privity. ${ }^{32}$ The appellate court explained that privity was mandated by a prior Supreme Court of Texas case; thus the court had no choice but to affirm the trial court's grant of a summary judgment in favor of the attorneys. ${ }^{33}$

The Supreme Court of Texas reversed and held that "there is no legal bar preventing an estate's personal representative from maintaining a legal malpractice claim on behalf of the estate against the decedent's estate planners." 34 The court did not express an opinion as to whether the attorneys' conduct actually amounted to malpractice. ${ }^{35}$

Other states with a strict privity approach that have followed Texas and allowed the personal representative of the decedent's estate to bring a legal malpractice claim against the estate planning attorney include: Florida, Maine, Montana, New York, and Ohio.

The Florida Supreme Court has recognized a limited exception to the

28. See infra Appended Table.

29. Belt v. Oppenheimer, Blend, Harrison \& Tate, Inc., 192 S.W.3d 780 (Tex. 2006).

30. Id.

31. Id. at 782 .

32. See Belt v. Oppenheimer, Blend, Harrison \& Tate, Inc., 141 S.W.3d 706 (Tex. App.-San Antonio 2004), rev'd, 192 S.W.3d 780 (Tex. 2006) (affirming the trial court's ruling that there could be no cause of action due to lack of privity).

33. Id.

34. Belt, 192 S.W.3d at 782.

35. Id. at 789 . 
strict privity requirement of the intended third party beneficiary. ${ }^{36}$ In Espinosa v. Sparber, ${ }^{37}$ the Florida Supreme Court concluded there was no extrinsic evidence to show the plaintiff was an intended third party beneficiary. ${ }^{38}$ However, the court did state that the decedent's "estate, however, stands in the shoes of the testator and clearly satisfies the privity requirement."39

In 1999, Maine's Supreme Judicial Court addressed the issue of legal malpractice in estate planning in Nevin v. Union Trust Co. ${ }^{40}$ The Supreme Judicial Court concluded, "When there is a personal representative to assert the financial claims on behalf of the estate ... the better rule appears to be not to allow individual beneficiaries to assert claims." ${ }^{41}$ Maine restricted their exception to the strict privity approach by stating a third party beneficiary does not have standing when there is no privity between them and the estate planning attorney and when there is a personal representative of the estate. ${ }^{42}$ Maine follows the reasoning of Texas in declaring that the personal representative of the estate "stands in the shoes of the client" - therefore, privity exists. ${ }^{43}$

Recently, New York agreed with Texas that the estate stands in the shoes of the decedent, and thus "has the capacity to maintain the malpractice claim on the estate's behalf." 44

In Hosfelt v. Miller, ${ }^{45}$ the Ohio Court of Appeals held that the personal representative of a decedent's estate stands in the shoes of the decedent. ${ }^{46}$ Although Ohio has not specifically examined the issue of a personal representative of the estate as the plaintiff, " $t]$ he outcomes of various Ohio cases seem to presume ... that a personal representative of the estate has

36. See Espinosa v. Sparber, Shevin, Shapo, Rosen \& Heilbronner, 612 So. 2 d 1378 (Fla. 1993) (finding that while the daughter of the decedent did not have standing to sue, the estate could).

37. Espinosa v. Sparber, Shevin, Shapo, Rosen \& Heilbronner, 612 So. $2 d 1378$ (Fla. 1993).

38. Id. at 1380.

39. Id.

40. Nevin v. Union Trust Co., 726 A.2d 694 (Me. 1999).

41. Id. at 701 .

42. See id. ("Accordingly, we conclude that individual beneficiaries do not have standing to sue estate planning attorneys for malpractice when they are not the client who retained the attorney and when the estate is represented by a personal representative who stands in the shoes of the client.").

43. Id.

44. Estate of Schneider v. Finmann, 933 N.E.2d 718, 720 (N.Y. 2010) (quoting Belt v. Oppenheimer, Blend, Harrison \& Tate, Inc., 192 S.W.3d 780, 787 (Tex. 2006)).

45. Hosfelt v. Miller, No. 97-JE-50, 2000 WL 1741909, at*4 (Ohio Ct. App. Nov. 22, 2000).

46. See id. (citations omitted) ("Thus, a personal representative of a decedent's estate stands in the shoes of the decedent to assert claims on behalf of the estate."). 
standing to assert legal malpractice claims." 47

Kansas is the only state up to date that has distinguished the reasoning of the Texas Supreme Court in Belt. The Kansas Supreme Court stated, "A cause of action does not survive in favor of a personal representative of a decedent unless it accrued in favor of the decedent in his or her lifetime." 48 The Kansas Supreme Court only distinguished Belt in regards to when a legal malpractice claim accrues; therefore, Kansas does not completely reject the notion of a personal representative of the decedent's estate as the plaintiff in a legal malpractice suit against the estate planning attorney. ${ }^{49}$

\section{Potentially Negligent Conduct}

\section{A. Poor Client Interactions}

\section{Failure to Gather Sufficient Information}

The attorney must conduct a very detailed client interview and compile a vast array of data before preparing the estate plan. This includes gathering information concerning the client's assets, liabilities, family situation, disposition desires, and related matters. Failure to obtain relevant facts makes it difficult or impossible to draft an appropriate estate plan. A client may not reveal certain important information merely because the attorney did not ask; moreover, the client may not realize the material's significance. Detailed client interview forms and checklists increase the likelihood of discovering relevant information.

2. Believing Client Without Independent Verification

A client unskilled in legal matters may inadvertently-or even intentionally-mislead the estate planner. To avoid unexpected surprises, the attorney should ask for supporting documentation whenever possible. This may include:

1) Information regarding family matters-marriages, divorces, birth of children, adoptions;

2) Ownership of assets- deeds, stock certificates, bonds;

47. Id. at $* 5$.

48. Jeanes v. Bank of Am., N.A., 295 P.3d 1045, 1052 (Kan. 2013) (citation omitted).

49. See id. at 1051 (stating that under Kansas case law, a legal malpractice cause of action accrues when a "fact of injury becomes reasonably ascertainable to the injured party"). 
3) Employee benefits—retirement plans, bonus plans, annuities;

4) Bank accounts—statements, passbooks, certificates of deposit, account contracts, signature cards;

5) Debts-promissory notes, deeds of trust, mortgages;

6) Life insurance-policies and beneficiary designations; and

7) Other relevant matters - powers of attorney, directives to physicians.

Clients frequently believe that documents reflect specific facts when in actuality they do not. A simple example is instructive. The client tells the attorney that he has a large certificate of deposit in his name and his best friend's name. The client explains he wants this certificate to pass to his friend, rather than to his family under his will. He assures the attorney that the certificate is in survivorship form and the attorney does not independently verify this assertion. When the client dies, the attorney discovers that the friend's name was either not on the certificate or that the certificate lacked survivorship language. The friend goes away empty handed and the client's intent is frustrated.

\section{Neglecting Communications with Client}

The attorney must be aware of the importance in maintaining communication with the client both during and after the preparation of the estate plan. During the estate planning process, the client may have questions or wish to make changes. This is often the case once a client begins thinking seriously about the disposition of family heirlooms. A better estate plan will result if the attorney promptly returns telephone calls and answers letters.

After the estate plan is complete, the attorney should maintain contact with the client unless the attorney makes it very clear that the representation does not continue beyond document execution. The client should understand that a change in circumstances necessitates a change to the will. This may include birth, marriage, adoption, death, substantial increase or decrease in assets, change in state of domicile, or change in state or federal law. 
4. Failure to Act Timely

An estate plan should be completed in a timely fashion. ${ }^{50}$ Obviously, this is imperative if the client is elderly or seriously ill. Prompt estate planning is also necessary even if a client is young and in perfect health at the time of the initial interview; the person could sustain a fatal automobile accident or heart attack on the way home. Thus, it may be wise to have the client execute a simple will, even a holographic one, at the time of the initial interview to accomplish at least a portion of the client's estate planning objectives. A one page will leaving all the client's property to the surviving spouse and appointing the spouse as the independent executor is often a desirable alternative to an intestate division between the spouse and children; such as would occur with community property if all the deceased spouse's descendants were not also the surviving spouse's descendants ${ }^{51}$ or if the deceased spouse owned separate property. ${ }^{52}$

5. Failure to Document Unusual Requests and Recognize Situations Leading to a Will Contest

If a client makes an estate planning decision that the attorney fears may appear suspicious to others or might be viewed as evidence of the attorney's negligence, special steps are necessary. For example, a married individual may want to leave the entire estate to the spouse or more than the amount not subject to federal or state estate tax to a non-spouse and thus incur estate tax liability that could have easily been avoided. The attorney should outline and explain the potential outcomes to the client in writing and then have the client sign a copy acknowledging that the client is aware of the ramifications of the decision.

The attorney must always be on guard when drafting unusual requests or instruments that may supply incentive for someone to contest a will or other estate planning documents. Anytime an individual takes more through intestacy or under a prior will, the potential for a will contest exists, especially if the estate is large. The prudent attorney must recognize situations that are likely to inspire a will contest and then take steps to

50. See generally Gerald P. Johnston, Legal Malpractice in Estate Planning and General Practice, 17 MEM. ST. U. L. REV. 521, 534-36 (1987) ("Procrastination may be an even greater problem in the trusts and estates field than it is in other areas.").

51. See Tex. Est. CODE ANN. $\$ 201.003(b)(2)$ (West 2014) (clarifying the disposition of community property of an intestate person).

52. See id. $\$ 201.002$ (c)(1) (entitling the surviving spouse to a decedent's separate property). 
reduce the probability of a will contest and the chances of its success. ${ }^{53}$

\section{B. Errors in Will Drafting 54}

\section{Poor Proofreading of Documents}

Many mistakes in estate planning documents result from poor proofreading. In a fast paced office, time pressure may restrict the attorney's opportunity to carefully review the documents. Under no circumstances should a client sign an estate planning document without both the attorney and the client carefully reading and analyzing the final draft. It may also be advisable for another attorney to review the documents. Major errors-e.g., a misplaced decimal point in a legacy or an important provision omitted - as well as seemingly minor errors, such as misspelling of beneficiary's name, may provide the focus of later litigation.

\section{No Specific Provision Regarding Ademption and Lapse}

Ademption, i.e., failure of a gift, occurs when the item given in the will is no longer in the testator's estate at time of death. ${ }^{55}$ For example, if the will gives Blackacre to $\mathrm{X}$ and testator sells or gifts Blackacre prior to death, $\mathrm{X}$ takes nothing under this provision of the will. In addition, the intended beneficiary will normally not receive the equivalent value via proceed tracing or otherwise. ${ }^{56}$ Accordingly, it is important for specific gifts to contain an express statement of the testator's intent if the item is not in the estate. The testator should explain either that ademption causes the intended beneficiary to go home empty handed or provide a substitute gift-e.g., other specific property, money, or a greater share of the residuary.

Unlike ademption, lapse occurs when a gift fails because the beneficiary

53. See generally Gerry W. Beyer, Will Contests-Prediction and Prevention, 4 EST. PLAN. \& COMM. PROP. 1, 6 (2011) (outlining the importance of drafting a proper will to avoid a will contest).

54. This section was prepared under Texas law. The general principles, however, should be applicable under the law of most jurisdictions.

55. See Rogers v. Carter, 385 S.W.2d 563, 565 (Tex. Civ. App.-San Antonio 1964, writ refd n.r.e.) (detailing the general rule of ademption).

56. See Shriner's Hosp. for Crippled Children of Tex. v. Stahl, 610 S.W.2d 147, 150 (Tex. 1980) (determining that beneficiaries do not receive the value of adeemed property); Opperman v. Anderson, 782 S.W.2d 8, 10 (Tex. App.-San Antonio 1989, writ denied) (finding that certain bequests are specific and subject to ademption). 
predeceases the testator. Unless the anti-lapse statute applies, the subject matter of the gift will then pass under the will's residuary clause, or, if the lapsed gift was the residuary, via intestacy. The anti-lapse statute saves the gift for the beneficiary's descendants if the beneficiary was a descendant of the testator-e.g., child, grandchild-or if the beneficiary was a descendant of the testator's parent-e.g., brother, sister, niece, nephew. ${ }^{57}$

To prevent the result of lapse from being governed by rules that may not comport with the testator's intent, each gift should expressly indicate who receives the property in the event of lapse. For example, the testator could make an express gift over to a contingent beneficiary, indicate that the gift passes to the descendants of a deceased beneficiary, or merely state that the gift passes via the residuary clause.

\section{Including Payment of "Just Debts" Provision}

The traditional, but inappropriate, direction to the executor to pay "just debts" should not be included in a will:

A specific will clause requiring that the executor pay all of the testator's "just debts" raises the question whether the executor is required to pay debts barred by limitations, and whether the executor is required to pay installments on long-term indebtedness that are not yet due. ${ }^{58}$

\section{Failure to Discuss Exoneration and Abatement}

Texas had long followed the doctrine of exoneration, that is, debts on specifically gifted property paid from other estate assets so that the beneficiary receives the asset unencumbered, rather than just the testator's equity. ${ }^{59}$ The doctrine has been abolished for wills executed on or after September 1, 2005. A specific gift passes subject to each debt secured by the property that exists on the date of the testator's death under Estates Code sections 255.252-.253. However, the testator may expressly provide in the will for the debts against a specific gift to be exonerated. Accordingly, the will should expressly indicate whether debts against specifically gifted property are to be exonerated and if so, from what

57. See EST. $\$ \$ 255.153-.154$ (outlining the anti-lapse statute).

58. Bernard E. Jones, 10 Drafting Mistakes You Don't Want to Make in Wills and Trusts (and How to Avoid Them), in UnIV. TeX. CLE, 8TH ANNUAl Estate PlanNing, GuARDianshiP, AND ELDER LAW CONFERENCE, Tab B, at 5 (2006).

59. See Currie v. Scott, 144 Tex. 1, 187 S.W.2d 551, 554 (1945) (demonstrating that a testator's debts are paid through the testator's estate). 
property.

While exoneration is possible, the Estates Code mandates the order in which gifts fail if the estate has insufficient property to satisfy all testamentary gifts. ${ }^{60}$ This order may or may not be in accordance with the testator's intent. Thus, the attorney must ascertain the relative strength of each gift and ensure the testator's primary beneficiaries receive preferential treatment either under the statute or by expressly altering the abatement order.

\section{Failure to Extend Survival Period}

Unless the will states otherwise, a beneficiary need only outlive the testator by 120 hours to take under the will. ${ }^{61}$ This length of time is typically too short. The purpose of requiring survival is to prevent multiple administrations of the same property within a short period of time and thus save administration expenses and estate tax. This goal however, is not effectuated by a period of a 120 hours; probate takes considerably longer than five days. Therefore, a testator should consider extending the survival period to a more realistic length of time, e.g., three, six, nine, or twelve months - a survival period of over six months will prevent a gift to a surviving spouse from qualifying for the marital deduction. ${ }^{62}$

\section{Failure to Address Tax Apportionment}

Apportionment refers to whether transfers that occur because of a person's death-e.g., gifts under a will, life insurance proceeds, survivorship bank accounts - will be reduced by the amount of estate tax attributable to the transfers. The Texas Estates Code provides a detailed apportionment scheme. ${ }^{63}$ This scheme may or may not reflect the testator's intent. As a result, the testator must be carefully questioned regarding tax apportionment desires in cases where the estate may be large enough to have estate tax liability.

60. See EST. $\$ 355.109$ (“[A] decedent's property is liable for debts and expenses of administration").

61. See id. $\$ \$ 121.101-.102$ (stating that unless a devisee "does not survive the testator by 120 hours" then the devisee is treated as if they passed away before the testator).

62. See I.R.C. $\$ 2056$ (b)(3) (1997) (noting an interest will not be considered to terminate if it does not exceed six months).

63. See EST. $\$ 124.005$ (listing the general apportionment of estate tax and its exceptions). 
7. Failure to Address Pretermitted, Adopted, and Non-marital Children

Under certain circumstances, children born or adopted after will execution are entitled to a share of the testator's estate. ${ }^{64}$ This automatic alteration of an established estate plan could have a devastating effect on the testator's disposition desires. For example, assume that the testator executes a will leaving the testator's entire estate to the American Red Cross. Thereafter, testator has a child and then dies without changing the will. The testator's intent to leave property to the American Red Cross would be completely ignored and the entire estate would pass to the child. Three methods may be used to avoid the application of the pretermitted child statute:

1) The will could expressly provide for the pretermitted heir, e.g., "I leave all my property to my children."

2) The will could mention the pretermitted child, e.g., "I intentionally make no provision for any child who may be hereafter born or adopted."

3) The testator may provide for the pretermitted child in some other manner such as by naming the child as a beneficiary of a life insurance policy.

All wills should address the pretermitted child issue, even those of individuals beyond child bearing years. It is becoming increasingly common for parents to adopt grandchildren and older individuals to adopt disadvantaged children-situations such as this increase the likelihood of triggering the pretermitted child statute.

The attorney must also carefully question the testator to ascertain the testator's desires regarding children who may be adopted or born out-of-wedlock. The testator may or may not wish these children to share in the estate in the same manner as biological children or children born during marriage. This issue is of particular importance when the testator makes class gifts, especially to grandchildren. ${ }^{65}$

64. See generally id. $\$ \$ 255.052-.056$ (showing a child born after the making of a will is entitled to part of the testator's estate despite not being mentioned in the will).

65. See Begleiter, supra note 16 , at 300 (indicating some court decisions have allowed grandchildren who were not explicitly mentioned in the will to be labeled as pretermitted heirs and were entitled to receive part of the testator's estate). 


\section{Inadequate Incorporation by Reference}

If the testator intends to incorporate an extraneous document by reference, the practitioner must make certain the document is in existence at the time of incorporation and sufficiently identified so that no other document could reasonably be referred to by the description. ${ }^{66}$ To avoid potential problems, especially if the document is short, the attorney should consider including the material within the body of the will rather than relying on incorporation. When a pour-over provision is included, the Estates Code requirements should be satisfied. ${ }^{67}$

\section{Failure to Externally and Internally Integrate Testamentary}

Documents

External integration is the process of establishing the testator's will by interpreting and construing various testamentary instruments left by the testator. The documents are pieced together to give effect to the latest statement of the testator's intent. Thus, a new will should be accurately dated and revoke all prior wills and codicils to clarify the testator's most recent desires. Because codicils increase the chance of external integration problems, they should be avoided unless special circumstances exist.

Proper internal integration guarantees the will fits neatly together as a unified document. Print all pages on the same kind and size of paper, use the same type style throughout the will, print the will with the same ribbon, ink cartridge, or toner cartridge, number each page in ex toto format (e.g., page 3 of 5), and avoid blank spaces. Additionally, securely fasten all pages together. These precautions help reduce the chance of the testator or third parties inserting or removing pages. Moreover, these steps easily demonstrate that the pages present at the time of the will execution ceremony are the same pages offered for probate.

66. See Allday v. Cage, 148 S.W. 838, 839-40 (Tex. Civ. App.-Fort Worth 1912, no writ) (identifying that if an extraneous document is trying to be incorporated into a will, a complete description of the document must be referenced). Contra UNIF. PROBATE CODE $\$ 2-513$ (describing the differences between the Texas Estate Code and the Uniform Probate Code). A limited number of states and the UPC authorize a testator to use a separate writing to dispose of tangible personal property even though that writing: (a) does not meet the requirements of a will and thus could not be probated as a testamentary instrument, (b) was not in existence at the date of will execution and thus could not be incorporated by reference, and (c) exists for no reason other than to dispose of property at death and thus could not be a fact of independent significance. Id. Texas is not one of these states and a will should not use this technique.

67. See EST. $\$ 254.001$ (showing an outside document can be incorporated into a will). 
10. Imprecise Use of Language

Ambiguity is one of the most frequent causes of will litigation. Care must be taken to phrase the will clearly and precisely. Choose words to avoid doubt as to their intended meaning. If potentially ambiguous words are used, unambiguous definitions should be included. An attorney should be especially leery of using the following words and phrases: cash, ${ }^{68}$ money, ${ }^{69}$ funds, ${ }^{70}$ personal property, ${ }^{71}$ issue, ${ }^{72}$ and heirs. ${ }^{73}$ The descriptions of specific gifts ${ }^{74}$ and designations of beneficiaries ${ }^{75}$ must be precise especially in light of the Supreme Court of Texas opinion, San Antonio Area Foundation v. Lang, ${ }^{76}$ which held "extrinsic evidence is not admissible to construe an unambiguous will provision." 77

Instructions in a will regarding the disposition of property must be mandatory to be enforceable. Precatory language, such as I wish, I would like, and I recommend, is normally considered suggestive in nature and not binding on the beneficiary. ${ }^{78}$ Precatory language has no place in a will. The testator should use a non-testamentary separate document if he or she wishes to express non-mandatory desires. If the testator insists on placing such language in the will, the attorney should add language indicating that the suggestions are merely precatory and have no binding effect.

68. See Stewart v. Selder, 473 S.W.2d 3, 9 (Tex. 1971) (showing the proper interpretation of the term cash may require some factual background).

69. See W. Tex. Rehab. Ctr. v. Allen, 810 S.W.2d 870, 873-74 (Tex. App.-Austin 1991, no writ) (identifying terms may have an alternate intended meaning).

70. See id. at 874 (noting the terms funds and money can be used interchangeably if the testator intends to do so).

71. See Gilkey v. Chambers, 146 Tex. 355, 207 S.W.2d 70, 73 (1947) (stating an alternate meaning for the term personal property).

72. See Munger v. Munger, 298 S.W. 470, 475 (Tex. Civ. App.-Dallas 1927, writ refd) (claiming the intent of the testator should be followed).

73. See Fed. Land Bank of Hous. v. Little, 130 Tex. 173, 107 S.W.2d 374, 377 (1937) (showing the term heirs can have multiple interpretations).

74. In re Estate of Cohorn, 622 S.W.2d 486, 488 (Tex. App.-Eastland 1981, writ refd n.r.e.). n.r.e.).

75. Hultquist v. Ring, 301 S.W.2d 303, 306 (Tex. Civ. App.-Galveston 1957, writ refd

76. San Antonio Area Found. v. Lang, 35 S.W.3d 636 (Tex. 2000).

77. Id. at 637.

78. See Najvar v. Vasek, 564 S.W.2d 202, 210 (Tex. Civ. App.-Corpus Christi 1978, writ ref $d$ n.r.e.) (expressing there is no specific language that is required to create a will); Wattenburger $v$. Morris, 436 S.W.2d 234, 239-40 (Tex. Civ. App.-Fort Worth 1968, writ refd n.r.e.) (showing that some provisions should be avoided in a will because they are not binding in nature). 


\section{Inadvertent Creation of Election Will}

"The principal of election is, that he who accepts a benefit under a will, must adopt the whole contents of the instrument, so far as it concerns him; conforming to its provisions, and renouncing every right inconsistent with it."79 Election provisions are occasionally placed in wills, where one spouse wants to dispose of the entire interest in some or all of the community property. The surviving spouse may consent to the disposition of the surviving spouse's share of the community assets because the will gives the spouse a significant interest in the deceased spouse's community or separate property. Attorneys must be careful, however, not to inadvertently create an election situation. Although there is a presumption that an election will be imposed only if the will is open to no other construction, an attorney could create an election scenario without having this intention. ${ }^{80}$ Thus, the will should include a provision expressly stating the testator's intent regarding election.

\section{Violation of Rule Against Perpetuities}

The Texas Constitution provides: "Perpetuities ... are contrary to the genius of a free government, and shall never be allowed." ${ }^{11}$ Under the Rule Against Perpetuities, an interest is not good unless it must vest, if at all, not later than twenty-one years after some life in being at the time of the creation of the interest, plus a possible period of gestation. ${ }^{82}$ Drafting wills demands extra precaution to ensure the rule is not violated. If the Rule is violated, the Texas courts must reform or construe the interest to effect the ascertainable general intent of the testator. ${ }^{83}$

\section{Inadequate Tax Planning}

An attorney, even one who infrequently prepares estates with tax consequences, must be able to recognize situations where tax planning is needed and then ensure the testator obtains proper advice. A commonly cited excuse for inadequate tax planning is a false belief that the estate is too small to incur estate tax. While property may not be in a decedent's

79. Philleo v. Holliday, 24 Tex. 38, 44 (1859).

80. See Wright v. Wright, 154 Tex. 138, 274 S.W.2d 670, 674 (1955) (commenting that election can be created unintentionally).

81. TEX. CONST. art. I, $\$ 26$.

82. See Tex. Prop. Code ANN. $\$ 5.043$ (a) (West 2014) (stating an interest must not violate the Rule Against Perpetuities, if it does then it must be construed so that the rule is not violated).

83. See id. (showing the intent of the testator must try and be upheld). 
probate estate, this does not mean it will escape taxation. Life insurance proceeds, trusts, retirement plans, and other assets may be includable in the decedent's estate for tax purposes. Thus, the attorney must inquire about all types of assets and determine whether the client will obtain significant additional assets (e.g., via an inheritance from a wealthy parent). The areas posing the greatest danger of error are special use valuation, the generation-skipping tax, and the marital deduction. ${ }^{84}$ It is beyond the scope of this article to review the potential errors in tax planning.

\section{Failure to Provide for Independent Administration}

If the testator wishes to obtain the benefits of independent administration, appropriate language must be inserted in the testator's will. ${ }^{85}$ Failure to include this language means additional delay, either because a full dependent administration is needed or because of the time it takes to obtain consent of all beneficiaries and court approval of an independent administration. To avoid these problems, it is essential that the testator's desires regarding administration be documented in the will.

\section{Lack of Provisions Regarding Personal Representative}

A will should indicate at least one executor who would serve if the named executor is unwilling or unable to serve (e.g., dies, resigns, is or becomes incompetent, or does not want to assume fiduciary responsibilities). Naming an alternate, or successor, executor will save the time and expense of locating a successor as well as having the estate managed by a person selected by the testator rather than by the court or the beneficiaries. ${ }^{86}$

Once designated, the personal representative must post bond unless bond is waived in the testator's will, ${ }^{87}$ the personal representative is a corporate fiduciary, ${ }^{88}$ or bond is waived by the court in an independent administration. ${ }^{89}$ Although bond does provide some protection to beneficiaries from evil personal representatives, bond is expensive and

84. See generally Begleiter, supra note 16, at 366 (showing several areas are problematic and pose a malpractice threat).

85. TEX. EST. CODE ANN. $\$ \$ 401.001-.008$ (West 2014).

86. See id. $\$ \$ 361.152-.155,401.001-.008$ (approving the court to appoint a qualified person to administer the estate if needed).

87. Id. $\$ 305.101(\mathrm{~b})(1)$.

88. Id. $\$ 305.101(\mathrm{c})$.

89. See id. $\$ 401.005$ (noting a bond is required). 
reduces the amount of property available to the beneficiaries. The client's desires regarding bond must be ascertained and those wishes made clear in the will.

The Texas Estates Code provides the method for determining a personal representative's compensation. ${ }^{90}$ The testator may have a different intent, either that the personal representative is to serve without compensation or that a different method be used to compute compensation. Thus, the will should contain an express statement of testator's intent regarding compensation for the personal representative. ${ }^{91}$

\section{Improper Will Execution ${ }^{92}$}

The will execution ceremony provides a fertile field for error. One researcher concluded, "The majority of estate planning malpractice cases have involved execution errors." 93 The importance of the ceremony is manifest; without a proper execution, the will has no effect regardless of the testator's intent. A careless, hurried, or casual ceremony increases the likelihood that an error will occur. The best way to increase the chances that the ceremony encompasses all of the required formalities is to have a detailed form or checklist of elements and follow it closely for every ceremony. ${ }^{94}$

\section{Ceremony Procedure}

The will execution ceremony should be conducted by the attorney, not by the client or the attorney's staff. There are reports of attorneys mailing or hand-delivering unsigned wills to clients along with will execution

90. See generally id. $\$ \$ 352.001-.004$ (determining that compensation for a personal representative can be added or deducted at the discretion of the court).

91. See Stanley v. Henderson, 139 Tex. 160, 162 S.W.2d 95, 97 (1942) (concluding a specific statement regarding the testator's intentions about compensation, should be made in order to avoid statements that contradict each other).

92. This section was prepared under Texas law. The general principles, however, should be applicable under the law of most jurisdictions.

93. See Martin D. Begleiter, Attorney Malpractice in Estate Planning-You've Got to Know When to Hold Up, Know When to Fold Up, 38 U. KAN. L. REV. 193, 218 (1990) (analyzing decided cases where will execution errors were at issue).

94. See Gerry W. Beyer, The Will Execution Ceremony—History, Significance, and Strategies, 29 S. TEX. L. REV. 413, 421-25 (1988) (describing the need for an attorney to conduct a consistent will execution ceremony to avoid malpractice liability); Gerry W. Beyer, How to Conduct a Texas Will Execution, EST. PlAN. DEVEL. FOR TEX. PrOf., July 2012, at 1 ("One of the most crucial stages of a client's estate plan is the will execution ceremony ...."). 
instructions. ${ }^{95}$ Even if the instructions are correct, there is little assurance that they will be correctly followed. ${ }^{96}$ Some attorneys may allow law clerks or paralegals to supervise the ceremony. This practice is questionable not only because it increases the probability of error, but because the delegation of responsibility may be considered a violation of professional conduct rules proscribing the aiding of a non-lawyer in the practice of law. ${ }^{97}$

The testator, the disinterested witnesses, the notary, and the supervising attorney are the key players in the will execution ceremony. In the normal situation, no one else should be present. It is especially important to be certain no beneficiary under the will attends the ceremony as a precaution against claims of overreaching and undue influence.

\section{The Testator's Signature}

The will must contain the testator's signature. ${ }^{98}$ An unsigned will has no effect, regardless of other evidence proving the testator's intent, unless the testator's signature appears on the self-proving affidavit in which case the affidavit's signature is sufficient. ${ }^{99}$ If a testator is using a proxy signatory, appropriate documentation of why the testator is not personally signing is needed as well as evidence that the proxy signed at the testator's direction and in the testator's presence.

When wills for several people are being executed simultaneously (e.g., husband and wife), the possibility exists that they will sign the wrong wills. $^{100}$ In this case, neither will would be valid; the signing testator

95. See Hamlin v. Bryant, 399 S.W.2d 572, 575 (Tex. Civ. App.-Tyler 1966, writ refd n.r.e.) (examining an attorney who drafted a will and instructed a client how to complete the will execution ceremony). See generally Johnston, supra note 50, at $529 \mathrm{n} .43$ (reporting cases where an attorney impermissibly delegated will execution duties to a testator).

96. See Begleiter, supra note 93, at $221 \mathrm{n} .160$ (acknowledging the risks of giving a testator instructions for getting a will executed).

97. See Palmer v. Unauthorized Practice Comm. of the State Bar, 438 S.W.2d 374, 376 (Tex. Civ. App.-Houston [14th Dist.] 1969, no writ) (prohibiting will execution duties from being "performed by an unlicensed person, not an attorney, and who is untrained"); Gerry W. Beyer, The Role of Legal Assistants in the Estate Planning Practice, Est. Plan. DeV. FOR TeX. Prof., Apr. 1989, at 1,2-3 (observing that the execution of a will without a license is the unauthorized practice of law); see also Gail E. Cohen, Using Legal Assistants in Estate Planning, PrAC. LAW., Oct. 15, 1984, at 73, 74 ("To derive maximum benefits from using legal assistants, a lawyer should create a system for the legal assistant's work"); Robert S. Mucklestone, The Legal Assistant in Estate Planning, 10 REAL PROP. PROB. \& TR. J. 263 (1975) (analyzing the use of legal assistants in estate planning procedure).

98. TEX. EsT. CODE ANN. $\$ \$ 251.051-.106$ (West 2014).

99. Id.

100. See generally In re Estate of Pavlinko, 148 A.2d 528 (Pa. 1959) (considering the issue of a 
lacked intent for the signed document to be the will and the other document lacks the testator's signature. To avoid this possibility, only one will should be executed at a time and the wills should be inspected closely to ascertain that they were not inadvertently switched.

\section{Lack of Sufficient Witnesses}

A non-holographic will requires a minimum of two competent witnesses. ${ }^{101}$ Failure to have at least two witnesses is fatal to will validity, but if the witnesses sign the self-proving affidavit rather than the will, the attestation will be sufficient although the self-proving affidavit fails. ${ }^{102}$

Although the testator is not required to actually see the witnesses sign the will, the attestation must take place in the testator's presence. ${ }^{103}$ The term presence means a conscious presence, that is, "the attestation must occur where testator, unless blind, is able to see it from his actual position at the time, or at most, from such position as slightly altered, where he has the power readily to make the alteration without assistance." 104

A will beneficiary should not serve as one of the two required witnesses to a non-holographic will. Under Texas law, a gift to an attesting beneficiary is generally void. ${ }^{105}$ If the beneficiary is an heir who would have inherited had there been no will, then the beneficiary takes the smaller of the gift under the will and what the beneficiary's intestate share would have been. ${ }^{106}$ Alternatively, the gift may be saved via corroboration by one or more disinterested and credible persons. ${ }^{107}$

\section{Improperly Completed Self-Proving Affidavit}

A self-proving affidavit may be invalid for many reasons. The notary might fail to swear the testator or witnesses. ${ }^{108}$ The testator and both

\footnotetext{
husband and wife who mistakenly sign each other's wills).

101. EST. $\$ 251.051$.

102. Id. $\$ \$ 251.051, .102$.

103. Id. $\$ 251.051$.

104. Nichols v. Rowen, 422 S.W.2d 21, 24 (Tex. Civ. App.-San Antonio 1967, writ refd n.r.e.); see Morris v. Estate of West, 643 S.W.2d 204, 206 (Tex. App.-Eastland 1982, writ refd n.r.e.) (finding that an attestation is outside of testator's presence when a testator is required to walk down a hallway and peer through a doorway to see the witnesses sign their names).

105. EST. $\$ 254.002$.

106. $I d$.

107. Id.

108. See Broach v. Bradley, 800 S.W.2d 677, 678 (Tex. App.-Eastland 1990, writ denied) (rejecting a self-proving affidavit as invalid due to improperly sworn witnesses).
} 
witnesses might not sign the affidavit. Although the testator or witnesses sign the affidavit, one or more may not have signed the will. In this case, the signatures on the affidavit may be used to bootstrap the will but the self-proving affidavit would be ineffective. ${ }^{109}$ Although not a condition to the affidavit's validity, the notary should record the ceremony in the notary's record book. ${ }^{110}$ This record may provide helpful evidence if a will contest ensues.

\section{Execution of Duplicate Originals}

A testator should never execute duplicate originals. Problems arise when, at time of death, all of the duplicate originals cannot be located. The general presumption is that the destruction of one duplicate original by the testator with intent to revoke operates to revoke all copies. ${ }^{111}$ However, this presumption may be rebutted by evidence that to avoid confusion resulting from having multiple last wills, the testator destroyed one of them intending to strengthen the validity of the other. ${ }^{112}$

\section{Errors in Trust Drafting ${ }^{13}$}

Special opportunities for error exist in trust drafting. Many of the items discussed in the will drafting section are applicable to trust drafting as well.

\section{Failure to Address Principal and Income Issues}

The Trust Code contains extensive provisions regarding the method of crediting a receipt or charging an expenditure to the principal or income of the trust. ${ }^{114}$ Depending on the circumstances, this may or may not be in accordance with the settlor's intent. Thus, the trust instrument should contain an express provision addressing how to allocate principal and income (e.g., specific rules, follow the Trust Code rules, or left to the trustee's discretion).

109. EST. $\$ 251.102$.

110. TEX. GOV’T CODE $\$ 406.014$ (West 2013).

111. Combs v. Howard, 131 S.W.2d 206, 209 (Tex. Civ. App.-Fort Worth 1939, no writ).

112. See id. at 210 (acknowledging that when a duplicate will is destroyed with the perspective of preventing any confusion from having two wills "it cannot be said that the destruction of the one for that purpose raised a presumption that she intended to revoke the other").

113. This section was prepared under Texas law. The general principles, however, should be applicable under the law of most jurisdictions.

114. See generally TeX. Prop. CodE ANN. $\$ 116$ (West 2014) (explaining uniform principle and income of trusts). 


\section{Omission of Spendthrift Provision}

If the trust is silent on the issue, the beneficiary has tremendous control over the beneficiary's trust interest; the beneficiary may sell it or give it away. In addition, the beneficiary's creditors may reach the beneficiary's interest to satisfy their claims. However, the vast majority of settlors want to prevent the beneficiary from transferring the trust interest either voluntarily or involuntary. Therefore, a spendthrift provision is appropriate in almost all trusts. ${ }^{15}$

\section{Misstating Ability to Revoke}

The settlor must decide on the revocability of the trust. If the settlor desires flexibility, retention of the ability to revoke is paramount; however, if the settlor seeks tax benefits, the trust usually must be irrevocable. Under Texas law, a trust is presumed revocable unless the trust instrument expressly makes it irrevocable. ${ }^{116}$ Thus, if the trust is created for tax reasons and lacks an express irrevocability provision, the tax advantages may be lost. Likewise, if the settlor actually intends a revocable arrangement, inclusion of an irrevocability clause would be intent defeating.

\section{E. Other Troublesome Mistakes}

\section{Improper Document Preservation}

It is important for estate planning documents to be stored in appropriate locations. If documents are not available to the appropriate person when needed, the client may lose the benefits of executing the documents. The disposition of an executed document is simple in some cases. For example, a medical power of attorney should be delivered to the agent. Yet, in other cases, the proper receptacle for the document is less easily ascertained.

The proper disposition of a will is often a controversial issue. The original will should normally be stored in a secure location where it may be readily found after the testator's death. Thus, some testators keep the will at home or in a safe deposit box, while others prefer for the drafting

115. Id. $\$ 112.035$ (b) ("A declaration in a trust instrument that the interest of a beneficiary shall be held subject to a 'spendthrift trust' is sufficient to restrain voluntary or involuntary alienation of the interest by a beneficiary to the maximum extent permitted by [the Trust Code].”).

116. Id. $\$ 112.051(\mathrm{a})$. 
attorney to retain the will. The attorney should not suggest retaining the original will because the original is then less accessible to the testator. When the drafting attorney retains a will, the testator may feel pressured to hire the attorney to update the will and the executor or beneficiaries may feel compelled to hire that attorney to probate the will. Some courts in other jurisdictions hold that an attorney may retain the original will only "upon specific unsolicited request of the client." 117

If a will contest is likely, the client must be informed of the dangers of retaining the will, i.e., it increases the opportunity for unhappy heirs to locate and then alter or destroy the will. The attorney may need to urge the testator to find a safe storage place that will not be accessible to the heirs, either now or after death, but yet a location where the will is likely to be found and probated. Simultaneously, make certain not to suggest that the attorney may retain the will.

\section{Failure to Provide Client with Sufficient Post-estate Plan Instructions}

After the will and other estate planning documents are executed, the client should be informed of several important matters. For example, the client needs to realize that he or she must reconsider the plan if the client's life or circumstances change due to one of the following:

1) Births or adoptions;

2) Deaths;

3) Divorces;

4) Marriages;

5) Change in feelings toward beneficiaries and heirs;

6) A significant change in size or composition of estate;

7) Change in state of domicile; or

8) Change in state or federal law.

The client must also be told that mark-outs, interlineations, and other informal changes to estate planning documents, especially attested wills, are usually of no effect. ${ }^{118}$ Not only should these and other matters be discussed with the client in person, they should also be provided to the client in written form.

117. State v. Gulbankian, 196 N.W.2d 733, 736 (Wis. 1972).

118. See Leatherwood v. Stephens, 24 S.W.2d 819, 823 (Tex. Comm'n App. 1930, judgm't adopted) ("If the obliterations [to the will] were made after the will was executed ..., such act was futile and amounted to nothing."). 
3. Failure to Use Disclaimers Where Appropriate

Texas law permits the beneficiary of a will, trust, insurance policy, or like arrangement, as well as an heir, to disclaim property. ${ }^{119}$ A proper disclaimer has many potential benefits including tax savings under I.R.C. section 2518, liability avoidance (e.g., property has potential liability connected with it such as buried hazardous waste), and protecting assets from most of the disclaimant's creditors. The attorney must be aware of these and other reasons to disclaim property and give advice accordingly. ${ }^{120}$

\section{Failure to Plan for Disability and Death}

Research has demonstrated that approximately one-half of the population of the United States will be disabled for ninety days or more. ${ }^{121}$ Persons of age sixty or younger are more likely to become disabled within the next year than to die-nonetheless, attorneys are often lax in planning for the possibility that their clients will suffer from a debilitating disease, accident, or general deterioration of mental function due to senility or other disabling cause. ${ }^{122}$ Attorneys must recognize that disability planning is at least as important as death planning and make appropriate arrangements. ${ }^{123}$ Attorneys and their clients should evaluate the following techniques:

1) Stand-by trust;

2) Wage replacement insurance;

3) Long-term care insurance;

4) A durable power of attorney for property management;

5) A medical power of attorney;

119. TeX. EST. CODE ANN. \$\$ 122.001-.153 (West 2014).

120. See generally Bruce D. Steiner, Disclaimers: Post-Mortem Creativity, ProB. \& Prop., Nov.-Dec. 1990, at 43 (providing various practical illustrations for using disclaimers in different contexts).

121. See John J. Lombard, Jr., 10 Reasons Why You Should Be Recommending the Durable Power of Attorney to Clients, PROB. \& PROP., Jan.-Feb. 1987, at 28, 28 ("Life is filled with constant reminders of disability and its reality.... Despite this reality, planning for disability has only begun to receive appropriate attention.").

122. See Kent H. McMahan et al., Disability Planning for Executives and Professionals, 23 REAL PRop. Prob. \& TRUST J. 73, 73 (1988) (“[A]ccording to the 1964 Commissioner's Disability Table ... four owners of a business ... with an average age of 40 , the probability that one will die before age 65 is $72 \%$ but the probability that one of the owners will suffer a long-term disability before age 65 is $92.5 \%$.").

123. See id. ("Disability planning issues and opportunities have been overlooked by ... attorneys as well."). 
6) A mental health treatment declaration;

7) A self-declaration of guardian;

8) Directive to physicians;

9) An anatomical gift statement; and

10) A body disposition instrument.

\section{Potential ExPosure For BREACHES of Professional RESPONSIBILITY}

\section{A. Estate Planning for Both Spouses ${ }^{124}$}

Today you are meeting with a new estate-planning client. During the initial telephone contact, the client indicated a need for a simple plan, "nothing too complex" were the exact words. As you enter your reception area to greet the client, you are surprised to see two people waiting-the client and the client's spouse. The client explains that the client wants you to prepare estate plans for both of them. Your mind immediately becomes flooded with thoughts of the potential horrors of representing both husband and wife. You remember stories from colleagues about their married clients who placed them in an awkward position when one spouse confided sensitive information that would be relevant to the estate plan with the admonition to "not tell my spouse." You also recall the professional ethics rules which prohibit representing clients with conflicting interests. What do you do? What is the best way to protect the interests and desires of the client and the client's spouse and still avoid ethical questions as well as potential liability?

This scenario is replayed many times each day in law offices across Texas and the United States. The joint representation of a husband and wife in drafting wills and establishing a coordinated estate plan can have considerable benefits for all of the participants involved. However, depending on the circumstances, joint representation may result in substantial disadvantages to either or both spouses and may subject the drafting attorney to liability. The attorney's duties of loyalty and confidentiality in joint representations, as well as how conflict situations should be handled-whether the conflict is apparent initially or arises during the representation-can be gleaned from the Texas Disciplinary Rules of Professional Conduct.

124. Portions of this section are adapted from Gerry W. BEYER, TeXAS Practice: TeXaS LAW OF WILLS $\$ \$ 53.4-.7$ (3d ed. 2002). 


\section{Models of Representation for Married Couples}

When a married couple comes to an attorney's office for estate planning advice, they are unaware of the different forms of representation that are available, in addition to the specific factors they must consider to determine which form of representation is appropriate. The attorney has the burden to use any skills of observation and information gathering and apply the relevant professional conduct rules to help the couple make a choice that best fits their situation.

\section{a. Family Representation}

Under the concept of family representation, the attorney represents the family as an entity rather than its individual members. This approach attempts to achieve a common good for all of the participants, thus the attorney's duty is to the family interest, rather than the desires of one or both of the spouses. However, representation of the family does not end the potential for conflict between the spouses; it broadens the potential basis of conflict by adding other family members to the equation. Further, even if no conflicts of purpose between the spouses, the attorney may feel obligated to the family to discourage-or even prevent - the spouses from effectuating their common desires where those desires do not benefit the family as a whole (e.g., where the spouses choose not to take advantage of tax saving tools, such as annual exclusion gifts, in favor of retaining the assets to benefit themselves). This type of representation, at least for spousal estate planning purposes, is unnecessarily complicated and may even frustrate the common desires of the spouses. This model of representation has not been clearly recognized by the courts.

b. Joint Representation

Joint representation is probably the most common form of representation estate planners use to develop a coordinated estate plan for spouses. Joint representation is based on the presumption that the husband, wife, and attorney will work together to achieve a coordinated estate plan. In situations where the attorney does not discuss the specific representative capacity in which he or she will serve, joint representation serves as the "default" categorization. Despite its widespread acceptance, however, joint representation has its pitfalls.

One critical issue an attorney faces when representing multiple parties stems from the obligation to make sure the representation complies with the Texas Rules of Professional Conduct. Rule 1.6, which prohibits representation where it "involves a substantially related matter in which 
that person's interests are materially and directly adverse to the interests of another client of the lawyer," is the most relevant in the joint representation of a husband and wife. ${ }^{125}$ Additionally, Rule 1.6 provides that if in the course of multiple representation such a conflict becomes evident, the lawyer must withdraw from representing one or both of the parties. ${ }^{126}$

The rule does, however, contain a savings clause that permits the attorney to accept or continue representation where a conflict of interest exists if: (1) the attorney believes the representation will not become materially affected, and (2) both parties consent to the representation after complete disclosure of all of the potential disadvantages and advantages involved. ${ }^{127}$ Many attorneys, regardless of whether potential conflicts are apparent, take advantage of this part of the rule and routinely disclose all advantages and disadvantages and obtaining oral or written consent (or both) to the representation. This approach exceeds the minimum requirements of Rule 1.6 and helps protect all participants from unanticipated results. Of course, there are still situations that cannot be overcome by disclosure and consent, such as where the attorney gained relevant, but confidential, information during the course of a previous representation of one of the parties. In this type of situation, the attorney has no choice but to withdraw from the joint representation and recommend separate counsel for each spouse. The dangers of joint representation are discussed in greater detail below in section 2 .

\section{c. Separate Concurrent Representation of Both Spouses}

The theory of separate concurrent representation in spousal estate planning context allows a single attorney to undertake representation of both the husband and the wife, but as separate clients. All information revealed by either of the parties to the attorney is fully protected by confidentiality and evidentiary privileges, regardless of the information's pertinence to establishing a workable estate plan. Thus, one spouse may provide the attorney with confidential information that would be vitally important to the other spouse's estate plan, but the attorney would not be able to share that information because the duty of confidentiality would be

125. TeX. Disciplinary Rules Prof'L CONDUCt R. 1.06(b)(1), reprinted in TeX. Gov'T Code AnN., tit. 2, subtit. G, app. A (West 2014) (TeX. STATE BAR R. art. X, $\$ 9$ ).

126. Id. R. $1.06(\mathrm{c})$.

127. Id. 
superior to the duty to act in the other spouse's best interest. Proponents of this approach claim informed consent given by the parties legitimizes this form of representation. However, due to the confusion it creates for the attorney regarding to whom the duty of loyalty is owed and whose best interest is to be served, it is hard to understand why any truly informed person would consent. The dual personality this form of representation requires of the attorney has resulted in it being dubbed a "legal and ethical oxymoron." 128

\section{d. Separate Representation}

A final option for the attorney and the married clients is for each spouse to seek their own separate counsel. This approach is embraced by many estate planning attorneys as the best way to protect a client's confidences and ensure the client's interests are not compromised or influenced by another. By seeking independent representation, spouses forego the efficiency-in terms of money and time spent-joint representation offers, but they gain confidence that their counsel will protect their individual priorities rather than be diluted by the priorities of the spouse. Additionally, separate representation substantially decreases the potential to trap the attorney in an ethical morass because of unanticipated conflicts or unwanted confidences.

\section{Dangers of Joint Representation}

\section{a. Creates Conflicts of Interest}

A conflict of interest between the spouses or between the spouses and their attorney can arise for many reasons. These conflicts often do not become apparent until well into the representation. If the attorney is skillful, or lucky, the conflict can be resolved and the joint representation may continue. In other cases, however, the conflict may force the attorney to withdraw from representing one or both of the spouses.

b. Accommodating the Modern Family

With the frequency of remarriage and blended families in today's society, it is not surprising that non-traditional families are a ripe source of

128. Geoffrey C. Hazard, Jr., Exec. Dir., Am. L. Inst., Conflict of Interest in Estate Planning for Husband and Wife, Lecture at the Annual Meeting of the American College of Trust and Estate Counsel (Mar. 7, 1994), in 20 PROB. LAW., Summer 1994, at 1, 13. 
conflict. A stepparent spouse may not feel the need or desire to provide for children that, biologically, are not their own. This fact can come into direct conflict with the expectations of the parent spouse who may believe the children are entitled to such support and that the stepparent spouse is just being selfish. Alternatively, the spouses may be in conflict over how the estate plan should provide for "our" children, "your" children, and "my" children, and whether any of these classifications should receive preferential treatment.

\section{c. Bias Toward Spouse If Past Relationship with Attorney Exists}

Another potential conflict exists where one of the spouses has a prior relationship with the drafting attorney, regardless of whether that relationship is personal or professional. The longer, closer, and more financially rewarding the relationship between one of the spouses and the attorney, the less likely the attorney will be free from that spouse's influence. ${ }^{129}$ Because the spouses rely on the attorney's independent judgment to assist them in effectuating their testamentary wishes, it is important that neither party has any actual or perceived disproportionate influence over the attorney.

\section{d. Opposing Objectives Between Spouses}

Spouses may also have different ideas and expectations regarding the forms and limitations of support provided by their estate plan to the surviving spouse, their children, grandchildren, and so forth. By including need-based or other restrictions on property, one spouse may believe that the other spouse will be "protected," while the other spouse may view the limitations as unjustifiable, punitive, or manipulative. If one spouse has children from a prior relationship, that spouse may wish to restrict the non-parent spouse's interest in them via a QTIP trust or other

129. See James R. Wade, When Can a Lawyer Represent Both Husband and Wife in Estate Planning?, PROB. \& PROP., Mar.-Apr. 1987, at 13, 15 (cautioning attorneys about the potential conflicts that may arise when representing more than one member of the family). Wade warns:

Attention should also be given, prior to undertaking a representation of several family members, to the client or personal relationship which the lawyer has with one or other of the family members. The longer the relationship with one client, the less likely the independence from that client's influence. The more financially rewarding the relationship with one client, the less likely the independence from that client's influence. The closer the personal relationship, the less likely the independence from the client's influence. 
arrangement to the great dismay of the non-parent spouse who would prefer to be the recipient of an outright bequest. Ultimately, no one distribution plan may be able to satisfy the desires of both spouses. ${ }^{130}$

\section{e. Power Struggle Between Spouses}

One spouse may dominate the client side of the attorney-client relationship. If one spouse is unfamiliar or uncomfortable with the prospect of working with an attorney or if one spouse is unable, for whatever reason, to make their desires known to the drafting attorney, and instead simply defers to the other spouse, it will be difficult for the attorney to fairly represent both parties.

\section{f. A Faltering Marriage}

If the attorney seriously questions the stability of the marriage, it will be practically impossible to create an estate plan which contemplates the couple being separated only by death. As one commentator explained:

No court would permit a lawyer to go forward when such a situation involves partners in a partnership or the principals in a close corporation, or a trustee and beneficiary of a trust, or a corporation and its officers. The courts will not take a different view when the clients are husband and wife. $^{131}$

The case of In re Taylor ${ }^{132}$ is instructive for such situations. A law firm represented both the husband and wife in the preparation of their estate plans, including wills, powers of attorney, and some other business matters. ${ }^{133}$ Later, the law firm undertook to represent the husband in divorce proceedings against the wife. ${ }^{134}$ The wife sought to have the law firm disqualified from representing the husband. ${ }^{135}$ The trial court

130. See id. ("The potential for conflicts of interest also exist where the lawyer, acting as 'the family lawyer,' designs a multi-generation estate plan.”).

131. Geoffrey C. Hazard, Jr., Exec. Dir., Am. L. Inst., Conflict of Interest in Estate Planning for Husband and Wife, Lecture at the Annual Meeting of the American College of Trust and Estate Counsel (Mar. 7, 1994), in 20 PROB. LAW., Summer 1994, at 1, 14 (citation omitted).

132. In re Taylor, 67 S.W.3d 530 (Tex. App.-Waco 2002, no pet.).

133. See id. at 531 (holding mandamus relief was proper where the lower court failed to disqualify a law firm that initially represented both spouses, but subsequently represented the husband after the couple's interests became adverse).

134. Id. at 532 .

135. See id. at 531 (noting the law firm, "[a]s part of the estate planning process ..., also prepared wills and medical and financial powers of attorney for both [spouses]"). 
denied her motion and she appealed. ${ }^{136}$

The appellate court conditionally granted the wife's request for a writ of mandamus directing the trial court to vacate the order denying her motion to disqualify the law firm. ${ }^{137}$ The record clearly showed the law firm represented both the husband and wife with regard to the business and estate matters, and thus, there would be a conflict of interest for the law firm to represent the husband in the divorce action. ${ }^{138}$ Ultimately, the wife did not consent to the law firm's representation of the husband in the divorce, and the law firm was disqualified. ${ }^{139}$ As such, the trial court's failure to grant the wife's motion was a clear abuse of discretion. ${ }^{140}$

\section{g. Unbalanced Estate Assets Between Spouses}

Significant conflict may arise if one spouse has a separate estate that is of substantially greater value than that of the other spouse, especially if the wealthier spouse wants to make a distribution which differs from the traditional plan where each spouse leaves everything to the survivor and upon the survivor's death to their descendants. The attorney might generate a great deal of conflict between both parties if he or she provides information regarding the less-wealthy spouse's potential financial standing under the contemplated distribution if the wealthy spouse dies first.

Conflict may also exist in situations where one spouse wants to make a gift of property which the other spouse believes is that spouse's separate property and therefore not an item which the first spouse is entitled to give. The potential for this type of conflict is especially great where the spouses have extensively commingled their separate and community property.

\section{h. Forces Release of Confidentiality and Evidentiary Privileges}

Joint representation may force spouses to forego their normal confidentiality and evidentiary privileges. ${ }^{141}$ Disclosure of all relevant

136. Id. at 533 .

137. Id. at 534 .

138. Id. at 533.

139. Id. ("The record further shows that there is a dispute in the divorce proceeding about the effect of that agreement and that [the wife], having been represented by the [law] firm [in prior estate planning matters], has not consented to the firm's representation of [her husband] in the divorce case.").

140. Id. at 534 .

141. Information that is revealed by co-clients during joint representation is not protected by attorney-client privilege where the co-clients later become adverse parties. See RESTATEMENT 
information is the only way to work toward the common goal of developing an effective estate plan. In subsequent litigation between the spouses regarding the estate plan, none of the material provided to the attorney may be protected. ${ }^{142}$ However, release of these privileges protects the attorney by eliminating the potential conflict between the attorney's duty to inform and the duty to keep confidences. ${ }^{143}$

\section{i. Discourages Revelation of Pertinent Information}

The fact that there is no confidentiality between the spouses in joint representation situations may not be a problem if the spouses have nothing to hide and have common estate planning goals. On the other hand, joint representation can place one or both of the spouses in the compromising position of having to reveal long held secrets in the presence of their spouse-e.g., the existence of a child born out of wedlock. Even worse is the scenario where the spouse withholds the information leaving the other spouse vulnerable and unprotected from the undisclosed information which, if known, may have resulted in a significantly different estate plan.

\section{j. Increases Potential of Attorney Withdrawal}

A potential conflict that becomes an actual conflict during the course of representation may not prevent the attorney from continuing the representation if the spouses previously gave their informed consent. ${ }^{144}$ However, if the conflict materially and substantially affects the interests of one or both of the spouses, the attorney must carefully consider the

(THIRD) OF THE LAW GOVERNING LAWYERS $\$ 75$ (2000) (instructing that communications between co-clients and their lawyer are not privileged between them in subsequent adverse proceedings); see also Brennan’s, Inc. v. Brennan's Rests., Inc., 590 F.2d 168, 171-72 (5th Cir. 1979) (recognizing where representation is joint, "neither of the parties to th[e] suit can assert the attorneyclient privilege against the other as to matters comprehended by that joint representation").

142. See Teleglobe Commc'ns Corp. v. BCE Inc., 493 F.3d 345, 366 (3d Cir. 2007) ("When former co-clients sue one another, the default rule is that all communications made in the course of the joint representation are discoverable."); see also RESTATEMENT (THIRD) OF THE LAW GOVERNING LAWYERS $\$ 75$ (2000) (outlining that communications that qualify as privileged against third parties are not privileged between co-clients who become adverse parties in a later proceeding); Grace M. Giesel, End the Experiment: The Attorney-Client Privilege Should Not Protect Communications in the Allied Lawyer Setting, 95 MARQ. L. REV. 475, 521 (2011) (commenting disclosures to counsel under joint representation are not privileged if the parties become adverse).

143. See Brennan's, 590 F.2d at 172 (discussing the ethical implications of joint representation and recognizing the conflict between an attorneys duty of client confidentiality and duty to inform).

144. See MOdel Rules of Prof'L CONDUCT R. 1.7(b) (2014) (allowing lawyers to represent clients where there is a conflict of interests if the client gives written informed consent). 
negative impact that the conflict will have on the results of the representation and on the attorney's independent judgment. The prudent action may be withdrawal. A midstream withdrawal can be very disruptive to the estate planning process and result in a substantial loss of time (and even money) to both the spouses and the attorney.

\section{k. Creates Conflicts Determining When Representation Is Completed}

There is some question as to whether a spouse who sought joint representation in the creation of an estate plan can later return to the same attorney for representation as an individual. The determination as to when the joint representation ends is quite settled with respect to subsequent attempts to unilaterally revise the estate plan-it does not end. Any subsequent representation of either spouse that relates to estate planning matters would constitute information that the attorney would be obligated to share with the other spouse. Regarding other legal matters, representation "should be undertaken by separate agreement, maintaining a clear line between those matters that are joint and those matters that are individual to each client." 145

\section{Recommendations}

Decisions regarding the most appropriate form of representation for a husband and wife seeking estate planning assistance could be made by the attorney alone, based on any past experiences, independent judgment, and skills of observation regarding the potential for conflict between the spouses. The better course of action is for the attorney to explain the choices available to the spouses along with the related advantages and disadvantages and then permit the spouses to decide how they would like to proceed. The only two viable options are joint representation and representation of only one spouse. ${ }^{146}$ As previously mentioned, representation of the family as an entity and separate concurrent representation by one attorney are appropriate forms of representation for a husband and wife only in extremely rare cases.

145. Teresa Stanton Collett, And the Two Shall Become One . . Until the Lawyers Are Done, 7 Notre Dame J.L. ETHICS \& PUB. POl'Y 101, 141 (1993).

146. See Malcolm A. Moore, Representing Both Husband and Wife Ethically, ALI-A.B.A. EST. Plan. Course Material J., Apr. 1996, at 5, 7. 
a. Representation of Only One Spouse

This form of representation allows each of the spouses to be fully autonomous in dealing with their spouse's attorney. Only the information the client spouse is comfortable with sharing is revealed to the other spouse. As one commentator explained, "[I]t (separate representation for each spouse) is consistent with the present dominant cultural view of marriage as a consensual arrangement, and is most consistent with the assumptions about the attorney-client relationship." ${ }^{147}$ Where it is obvious to the attorney that the couple would be best served by separate representation, it is the attorney's responsibility to convince the couple of this fact. Certain situations should alert the attorney that separate representation is probably the best choice, such as where the marriage is not the first for either or both parties; where there are children from previous relationships; where one party has substantially more assets than the other; and where one spouse is a former client or friend of the attorney.

When recommending separate representation, the attorney should take care to point out that this suggestion is not due to an inference that their relationship is unstable or that one or both parties may have something to hide. Instead, it merely reflects that each spouse has their own responsibilities, concerns, and priorities that may or may not be exactly aligned with those of the other spouse. Accordingly, the best way to achieve a win-win result and reduce present and future family conflict is for each spouse to retain separate counsel.

\section{b. Joint Representation of Both Spouses}

Despite the potential dangers to clients and attorneys alike, joint representation is the most common form of representation of husband and wife for estate planning matters. With appropriate and routine use of waiver and consent agreements, the attorney may undertake this type of representation with minimal risk to himself, while maximizing efficiency for the clients. Unfortunately, it is far from standard procedure for attorneys to make use of disclosure and consent agreements. One survey suggests that over $40 \%$ of estate planning attorneys do not, as a matter of practice, explain to their clients that potential conflict exists in such a representation, much less put such an explanation in writing. ${ }^{148}$ One

147. Collett, supra note 145, at 128-29 (alteration in original).

148. See Francis J. Collin, Jr. et al., A Report on the Results of a Survey About Everyday Ethical Concerns in the Trust and Estate Practice, 20 ACTEC NOTES 201, $206-07$ (1994) (forwarding the 
attorney stated that he only felt it was necessary to discuss potential conflicts where the representation involved a second or more marriages, and that he only put it in writing if he felt a real problem was indicated in the first meeting. ${ }^{149}$ Another respondent chose not to disclose the potential for conflict because he was afraid it would appear like he was issuing a disclaimer for any mistakes he might make. ${ }^{150}$ Finally, it seems that denial of the existence of potential conflicts occurs on the part of the attorney as well as the spouses, as evidenced by one practitioner's statement, "I have a hard time believing that I should tell clients who have been married for a long time and who come in together to see me that there may be problems if they get a divorce." 151

The ABA Standing Committee on Ethics and Professional Responsibility issued Formal Opinion 05-434 that addresses conflicts which may arise when an attorney represents several members of the same family in estate planning matters. ${ }^{152}$ The opinion validates the common practice of one lawyer representing several members of the same family. ${ }^{153}$ The basis of this authorization is that the interests of the parties may not be directly adverse and that more than conflicting economic interests are needed before the attorney is precluded from representing both. ${ }^{154}$ Further, the opinion recognizes that current conflict of interest may result even without direct adversity if there is a significant risk that representation of one client will materially limit the representation of another. ${ }^{155}$

Despite the "permission" granted by this opinion, I continue to think the representation of more than one family member in estate planning matters is problematic. A potential conflict may later turn into a real conflict, leaving the attorney in an untenable position. It is simply not worth the risk. Rather, it is better for a lawyer to owe $100 \%$ of any duties to one and only one family member. This way, there will never be doubt

\footnotetext{
comments of attorneys who were surveyed as to whether they discuss potential conflicts among married couples).

149. See id. at 207 (exploring attorney's comments in response to the survey question).

150. Id. at 220 .

151. Id. at 219.

152. ABA Comm. on Ethics and Profl Responsibility, Formal Op. 05-434 (2004).

153. See generally id. (discussing the various ethical concerns of joint representation of multiple family members).

154. See id. at 2 (noting there must be a conflict of legal rights and duties, rather than mere economic interests for parties to be directly adverse).

155. See id. at 3 (relating that adverseness is not the only way in which a conflict of interest is created by joint representation).
} 
as to whom the attorney represents or what actions the attorney should take if a conflict becomes known. True, practitioners may lose some business and some clients may have higher legal fees, but this result is preferable to the alternative.

Nonetheless, many attorneys continue to represent spouses jointly. Attorneys who do so are strongly recommended to (1) provide the spouses with full disclosure and (2) obtain the spouses' written informed consent, regardless of the perceived potential for conflict. Informed consent is not possible without full disclosure. Because estate planning attorneys often meet one or both of the spouses for the first time the day of the initial appointment, it is not possible for an attorney to know more about the couple than what he or she sees and hears during the interview. Further, because there is no way to be sure which specific issues are relevant to the spouses, it is extremely important for an attorney to discuss as many different potential conflicts that may reasonably manifest. Even if an attorney has some familiarity with the couple, it is better to cover too many possibilities than too few.

The amount of disclosure that enables one to act with "informed" consent varies with each client. The attorney has the responsibility to seek information from the parties to be sure that all relevant potential conflicts are addressed as well as the effects of certain other incidents, such as divorce or death of one of the spouses. It is also a good idea to discuss the basic ground rules of the representation detailing exactly what is and is not confidential, rights of all parties to withdraw, and other procedural matters such as attendance at meetings and responsibility for payment of fees.

An oral discussion of potential conflicts that exist or that may arise between the couple will allow the attorney to gather information about the clients while disseminating information for them to use in making their decisions. Oral disclosure also permits a dialogue to begin that may encourage the clients to ask questions and thereby create a more expansive description of the advantages and disadvantages of joint representation as they apply to the couple. ${ }^{156}$

156. Though there is no rule or standard which requires that disclosure or the clients' consent be evidenced by a written document, the seriousness and legitimacy that go along with a signed agreement serve as additional protection for all participants. By documenting the disclosure statement and each client's individual consent to the joint representation, the couple may be forced to reconsider the advantages and disadvantages of joint representation and may feel more committed to the agreement. Additionally, if there are any issues which they do not feel were addressed in the document, they may be more likely to express them so that the issue can also be included in the 


\section{B. Representation of Non-spousal Relatives}

Representation of more than one family member raises a number of ethical concerns such as avoiding conflicts of interest, maintaining confidences, and preserving independent professional judgment. These issues are analogous to those discussed with regard to the representation of both spouses. The safest course of action would be to decline to represent two individuals from the same family, especially a parent and their child.

\section{Naming Drafting Attorney, Attorney's Relative, or Attorney's Employee as a Beneficiary}

Attorneys are often asked by family members, friends, and employees to prepare wills, trusts, and other documents involved with the gratuitous transfer of property. These same individuals may also want the attorney to name him or herself as one of the beneficiaries of the gift. This common occurrence is fraught with legal and ethical problems, since the attorney may not be able to claim the gift and may be subject to professional discipline.

\section{Effect on Validity of Gift}

Under Roman law, the drafter of a will could take no benefit under the will. ${ }^{157}$ Under modern law, the general rule still prohibits the drafter of a will from taking a benefit under the will. However, forty-six states and the District of Columbia have adopted the Model Rules of Professional Conduct (MRPC), including Rule 1.8(c), which prohibits an attorney from preparing a will giving the attorney or a person related to the attorney a substantial gift, unless the recipient is related to the client. ${ }^{158}$ The MRPC prohibits the drafter of the will from benefiting under the will, but with an exception if the attorney or person related to the attorney is related to the client. Although forty-six states and the District of Columbia have

\footnotetext{
agreement. Finally, reducing the agreement to written form helps protect the attorney should any future dispute arise regarding the propriety or parameters of the representation. Excellent forms are available on the website of the American College of Trust and Estate Counsel: htttp://www.actec.org/public/EngagementLettersPublic.asp.

157. See Elmo Schwab, The Lawyer as Beneficiary, 45 TEX. B.J. 1422, 1422 (1982) (discussing the ancient doctrine of "qui se scrip sit heredem").

158. See ACTEC Commentaries on the Model Rules of Professional Conduct, ACTEC (last visited Apr. 2, 2015), http://www.actec.org/public/CommentariesPublic.asp (identifying the states that have implemented and modified the Model Rules of Professional Conduct to reflect their state-specific rules of conduct).
} 
adopted the MRPC, there are various exceptions to the rule of the drafter being a beneficiary under the will, which varies from state to state. This also brings up the question concerning the validity of such gifts.

If the drafter of the will is a beneficiary under the will, many states provide that this benefit raises a presumption of undue influence, while some states automatically void the gift. ${ }^{159}$ Generally, a violation of the MRPC Rule 1.8(c) will not automatically void the gift, but instead the appropriate authority can impose a penalty ranging from a private reprimand to disbarment. ${ }^{160}$

\section{Effect on Ethical Duties}

The MRPC Rule 1.8(c) states:

A lawyer shall not solicit any substantial gift from a client, including a testamentary gift, or prepare on behalf of a client an instrument giving the lawyer or a person related to the lawyer any substantial gift unless the lawyer or other recipient of the gift is related to the client. For purposes of this paragraph, related persons include a spouse, child, grandchild, parent, grandparent or other relative or individual with whom the lawyer or the client maintains a close, familial relationship. ${ }^{161}$

The MRPC Rule 1.8(c) does not apply if the gift is not a substantial gift. ${ }^{162}$ While it is unclear whether a non-substantial gift is acceptable, the comment to Rule 1.8(c) indicates that it is: "a simple gift such as a present given at a holiday or as a token of appreciation is permitted." 163 However, the standard for what constitutes a substantial gift is unclear and should not be relied on by a drafter of the will who is also the beneficiary.

The MRPC provides an exception for attorneys (or someone related to the attorney) to receive gifts from clients. The exception applies when the recipient is related to the client. However, a prudent attorney should look to see how "related" is defined, as it may vary from state to state. Additionally, the rule does not prohibit the attorney from appointing

159. See Gerry W. Beyer, Wills, Trusts, \& Estates $\$$ 10.3.3.1 (5th ed. 2012) (noting that an attorney who writes a will and also lists himself as a beneficiary may lose the intended gift as a result of a presumption of undue influence).

160. See id. at $\$ 10.3 .3 .2$ (recognizing that the penalty range for a violation of MRPC Rule 1.8 (c) is determined on a case-by-case basis).

161. MODEL Rules of PROF'L CONDUCT R. 1.8(c) (2012).

162. See N. Gregory Smith, Beware of Clients Bearing Gifts, 54 LA. B.J. 250, 251 (Dec. 2006/Jan. 2007) (observing that a minor gift, such as a box of cookies, is not considered a substantial gift under MRPC Rule 1.8(c)).

163. MOdel Rules OF PROF'L CONDUCT R. 1.8(c) cmt. 6 (2012). 
another lawyer to draft the will, but the appointment would be subject to the general rules regarding conflicts of interest. ${ }^{164}$

\section{Naming Drafting Attorney as a Fiduciary}

The former Ethical Considerations provided, "A lawyer should not consciously influence a client to name him as executor [in a will] .... In those cases where a client wishes to name his lawyer as such, care should be taken by the lawyer to avoid even the appearance of impropriety." 165 This rule was interpreted to mean that a lawyer may be named as the executor for an estate "provided there is no pressure brought to bear on the client, and such appointments represent the true desire of the client." 166

Despite the authority to do so, the attorney must exercise great care to avoid potential claims of overreaching or conflict of interest. ${ }^{167}$ It is wise to have the client sign a plain language disclosure statement that explains the ramifications of the attorney serving as the executor. ${ }^{168}$ It is not uncommon for a will to have a provision exonerating the executor from liability for acts of ordinary negligence. A standard such clause is, "No executor shall be liable for its acts or omissions, except for willful misconduct or gross negligence." 169 These exculpatory clauses are generally upheld by Texas courts. ${ }^{170}$ However, if the executor doubled as

164. See id. (asserting that such a conflict exists when the attorney's interest in obtaining the appointment materially limits the attorney's independent professional judgment in informing and advising the client).

165. TEX. STATE BAR R., EC 5-6 (Tex. Code of Profl Resp.), reprinted in 23 BAYLOR L. REV. 697, 763 (1972).

166. State Bar of Tex. Comm. on Interpretation of the Canons of Ethics, Formal Op. 71 (1953), reprinted in Cullen Smith, Comment, The Texas Canons of Ethics Revisited, 18 BAYLOR L. REV. 183, 227 (1966).

167. See Howard M. McCue III, Flat-Out of the Will Business-A Recent Malpractice Case Results in an Expensive Settlement for Both Lawyer and Executor, TR. \& EST., Sept. 1988, at 66 (discussing San Antonio lawsuit which was settled when law firm agreed to pay over $\$ 4$ million to plaintiff; the attorney who drafted the will had named attorneys employed by the firm as executors).

168. See LARRY W. GIBBS, The Lawyer's Professional Responsibility in Estate Planning and Probate-Common Problems and Practical Solutions, in PRACTICAL WILL DrafTING AND Representing the Estate and the Beneficiaries in HARD Times, ch. F, 4-6, 24-26 (1987) (admitting that while there is no law which prohibits an attorney from acting as an executor, it is advantageous to provide a disclosure statement, for the client's signature, which limits the attorney from liability for acts of ordinary negligence).

169. See generally id. (providing an example of disclosure language limiting attorney liability).

170. See Corpus Christi Nat'l Bank v. Gerdes, 551 S.W.2d 521, 524 (Tex. Civ. App.-Corpus Christi 1977, writ ref d n.r.e.) (holding that an exculpatory clause in a trust document which removes the liability of a trustee for any mistake, error of judgment, or negligence is a binding provision on the beneficiaries as long as it does not authorize self-dealing). 
the attorney who drafted the will, it is not clear whether such a clause would be upheld in light of Rule 1.08(g) of the Texas Disciplinary Rules of Professional Conduct which states:

A lawyer shall not make an agreement prospectively limiting the lawyer's liability to a client for malpractice unless permitted by law and the client is independently represented in making the agreement, or settle a claim for such liability with an unrepresented client or former client with out first advising that person in writing that independent representation is appropriate in connection therewith. ${ }^{171}$

\section{E. Naming Drafting Attorney as Fiduciary's Attorney}

The Model Rules do not prohibit at attorney from including a provision directing a fiduciary to retain a particular lawyer's services. ${ }^{172}$ Most wills and trusts, however, do not contain these types of provisions; hence, the inclusion of such a clause may raise suspicions that the attorney improperly influenced their client. In addition, many courts will treat this type of provision as merely precatory and thus not binding on the fiduciary.

\section{F. Fiduciary Hiring Self as Attorney}

A fiduciary with special skills may be tempted to employ him or herself to provide those services to the estate or trust. For example, the trustee may be an attorney, accountant, stockbroker, or real estate agent. If the trustee succumbs to the temptation, the trustee will create a conflict of interest situation. As a fiduciary, the trustee should seek the best specialist possible within the trust's budget. However, as a specialist, the trustee wants to get the job and secure favorable compensation. Dual roles permit the trustee to engage in schizophrenic conversations such as, "this is too complicated for my trustee mind so I need to consult myself using my attorney brain."

Courts typically presume that self-employment is a conflict of interest and will not permit trustees to recover extra compensation for the special services. ${ }^{173}$ However, the court may permit the trustee to receive

171. TeX. Disciplinary Rules Prof'L CONDUCt R. 1.08(g).

172. See Model Rules of Prof'L CONDUCT R. 1.8 (2012) (advising the attorney to obtain the client's informed consent to any conflict that may arise from such an appointment).

173. See Mary Jane Ciccarello \& Edward D. Spurgeon, The Lawyer in Other Fiduciary Roles: Policy and Ethical Considerations, 62 FORDHAM L. REV. 1357, 1397 (1994) (noting that some jurisdictions, including California, may prohibit dual fees, unless it is specifically written into the will). 
compensation in dual capacities if the trustee can prove that the trustee acted in good faith for the benefit of the trust and charged a reasonable fee for the special services. ${ }^{174}$

\section{G. Attorney as Document Custodian}

It is important for estate planning documents to be stored in appropriate locations. ${ }^{175}$ If documents are unavailable to the appropriate person when needed, the client may lose the benefits of executing the documents. The disposition of an executed document is simple in some cases. For example, a medical power of attorney should be delivered to the agent. In other cases, however, the proper receptacle for the document is less easily ascertained.

The proper disposition of a will is often a controversial issue. The original will should normally be stored in a secure location where it may be readily found after the testator's death. Thus, some testators keep the will at home or in a safe deposit box, while others prefer for the drafting attorney to retain the will. The attorney should not suggest retaining the original will because the original becomes less accessible to the testator. ${ }^{176}$ When the drafting attorney retains a will, the testator may feel pressured to hire the attorney to update the will and the executor or beneficiaries may feel compelled to hire that attorney to probate the will. ${ }^{177}$ In other jurisdictions some courts hold that an attorney may retain the original will only "upon specific unsolicited request of the client." 178

If a will contest is likely, the client must be informed of the dangers

174. See id. at 1397-98 (advocating that the best approach is to allow the attorney/fiduciary to receive reasonable payment for dual roles when they can report to the court the particular work done for such payment).

175. See Rania Combs, Where Should I Store My Estate Planning Documents?, TEX. WILlS \& TRUSTS ONLINE (June 7, 2010), http://www.texaswillsandtrustslaw.com/2010/06/07/where-shouldi-store-my-estate-planning-documents/ (noting that in Texas estate documents can be stored in your home, in a safe deposit box, or they can be filed with the clerk of court at the courthouse for safekeeping).

176. See Jennifer A. Kosteva, Where There's a Will, There's a ... Duty?: A Closer Look at the Safekeeping of Clients' Original Estate Planning Documents 2 (2009), http://www.americanbar.org/ content/dam/aba/publications/rpte_ereport/2009/april/te_kosteva.authcheckdam.pdf (noting that an attorney's mere retention of a client's estate documents does not make the client a current client, nor does it impose any obligation on the attorney to inform the client of any legal developments or to keep apprised of any changes in the client's familial or financial status).

177. See id. at 5 (observing that many states caution the retention of original documents by an attorney may exert undue pressure on clients to retain the attorney for the estate's matters).

178. State v. Gulbankian, 196 N.W.2d 733, 736 (Wis. 1972). 
associated with retaining the will (i.e., it increases the opportunity for unhappy heirs to locate and then alter or destroy the will). The attorney may need to urge the testator to find a safe storage place that will not be accessible to the heirs, either now or after death, but rather a location where the will is likely to be found and probated. Additionally, the attorney must make certain not to suggest that the attorney retain the will.

\section{H. Capacity of Representation}

Generally, when an attorney represents a client, it is clear as to whom the attorney owes a duty. However, it is not as clear as to whom the client is when the attorney represents a fiduciary, such as custodian or guardian for a minor, an executor, trustee, or personal representative. ${ }^{179}$ Most jurisdictions have no laws regarding this issue, and those that have tried to provide some guidance adopts one of three major approaches: (1) the traditional theory, (2) the joint-client theory, or (3) the entity theory. ${ }^{180}$

The traditional theory dictates that the fiduciary is the client. The American Bar Association has adopted this approach and in those jurisdictions that have provided a clear ruling regarding who the client is, the traditional theory also seems to be the most prevalent theory. ${ }^{181}$ Some states that have indicated following the traditional approach are South Carolina, Michigan, and California (although California has not enacted specific legislation, California's case law indicates the adoption of the traditional theory). ${ }^{182}$ Indiana recently enacted legislation adopting the traditional theory. ${ }^{183}$ Additionally, the Supreme Court of Texas also

179. See Kennedy Lee, Representing the Fiduciary: To Whom Does the Attorney Owe Duties?, 37 ACTEC L.J. 469, 469 (2011) (expressing that confusion may exist as to who the client is and to whom the attorney owes a fiduciary duty).

180. See id. (identifying the three most common approaches that are adopted by jurisdictions regarding the capacity of representation).

181. See id. at 471-72 (adopting the traditional theory which is defined as, "the fiduciary is the sole client of the attorney and the attorney has no special duties or obligations to a beneficiary other than those negative duties an attorney owes to all third parties").

182. See id. (identifying the states which have passed legislation concentrating on who is the client when a fiduciary retains a lawyer)

183. See 2013 Ind. Acts 99 (enacting legislation regarding the duties of an estate lawyer to the estate's personal representative). More specifically, the code states that an estate lawyer:

(1) represents and owes a duty only to the personal representative;

(2) does not have a duty to collect, possess, manage, maintain, monitor, or account for estate assets, unless otherwise required by a specific order of the court; and

(3) is not liable for any loss suffered by the estate, except to the extent the loss was caused by the estate lawyer's breach of a duty owed to the personal representative. 
adopted the traditional theory in Huie v. DeShazo. ${ }^{184}$

The joint-client theory finds that a "beneficiary is entitled to essentially the same duties as the fiduciary is entitled" and therefore is a joint-client with the fiduciary. ${ }^{185}$ Professor Hazard illustrates the joint-client theory with a triangle metaphor: the first leg is the attorney-fiduciary relationship, the second leg is the fiduciary-beneficiary relationship, and the third leg is the attorney-beneficiary relationship. ${ }^{186}$ Although courts that follow the joint-client theory recognize that the beneficiary and the fiduciary are both clients of the attorney, there is disagreement as to whether the two clients are identical in relation to the attorney. ${ }^{187}$ Jurisdictions that seem to follow the joint-client theory include: Nevada, Washington, Delaware, New Jersey, and Arizona. ${ }^{188}$

Under the third approach, the entity theory, "the estate is considered a separate legal entity and the estate, not the fiduciary or the beneficiary, will be considered the client." ${ }^{189}$ The estate is treated as if the client was a business entity. ${ }^{190}$ Similar to how a corporation would act through an agent, the estate "would act through the fiduciary as its agent." 191 Under the entity theory, the attorney for the fiduciary would become a co-agent of the estate and therefore, responsible to the estate instead of the fiduciary agent. ${ }^{192}$ As a co-agent of the estate, the attorney would owe not only a duty to the estate, but also to all interested parties, including beneficiaries. ${ }^{193}$ Michigan used to follow the entity approach, however, an amendment to the Michigan Probate Code clarified to whom an attorney owes a duty, and adopted the traditional theory. ${ }^{194}$

\footnotetext{
2013 Ind. Acts 99.

184. Huie v. DeShazo, 922 S.W.2d 920 (Tex. 1996).

185. Lee, supra note 179 , at 477.

186. See id. at 477-78 (exemplifying the three legs of Professor Hazard's triangle metaphor of joint-client theory).

187. See id. at 478 (asserting that some courts believe that one client takes precedence over the other client).

188. See id. at 477-78 (recognizing the limited number of states which have adopted the jointclient theory).

189. Id. at 485 .

190. See id. (asserting that the attorney "must give his first and only allegiance to the estate").

191. Id. estate).

192. See id. (concluding that the attorney's client would not be the fiduciary, but the principal

193. See id. at 486 ("The attorney, as co-agent, would therefore have duties to the estate and all its interest parties, including the beneficiaries.").

194. See id. (observing that due to the amendment by the Michigan Probate Court Rules the attorney's client is the fiduciary and not the estate or a fictional entity, such as the business entity
} 


\section{CONCLUSION}

"Sleep with one eye open. Gripping your pillow tight."195

Now that does not sound like any fun, does it? However, if you are careful and follow the advice in this article, you can endeavor to make your estate planning practice free from malpractice and ethical issues. And then, you can get the good night's sleep you deserve.

method).

195. METALliCA, ENTER SANDMAN (Elektra Records 1991). 


\section{APPENDIX}

The following table summarizes the approaches to estate planning malpractice adopted by the various states. ${ }^{196}$ Please note that this table is a work in progress so if you notice anything that needs to be corrected, updated, or revised, I would greatly appreciate your comments.

\begin{tabular}{|c|c|c|c|c|}
\hline Jurisdiction & $\begin{array}{c}\text { Privity } \\
\text { Required? }\end{array}$ & Approach & Authority & Comments \\
\hline Alabama & Yes & $\begin{array}{l}\text { Strict } \\
\text { Privity }\end{array}$ & $\begin{array}{l}\text { Robinson v. } \\
\text { Benton, } 842 \text { So. } \\
\text { 2d 631 (Ala. } \\
\text { 2002); Alabama } \\
\text { Legal Services } \\
\text { Liability Act ALA. } \\
\text { CoDE \$ 6-5-571 } \\
\text { (1988). }\end{array}$ & $\begin{array}{l}\text { Alabama follows the strict } \\
\text { privity approach. }\end{array}$ \\
\hline Alaska & Yes & $\begin{array}{l}\text { Strict } \\
\text { Privity }\end{array}$ & $\begin{array}{l}\text { Linck v. Barokas \& } \\
\text { Martin, } 667 \text { P.2d } \\
171 \text { (Alaska } \\
\text { 1983). }\end{array}$ & $\begin{array}{l}\text { Alaska follows the strict } \\
\text { privity approach. }\end{array}$ \\
\hline Arizona & No & $\begin{array}{c}\text { Broad } \\
\text { cause of } \\
\text { action } \\
\text { (balancing } \\
\text { factors) }\end{array}$ & $\begin{array}{l}\text { Capitol Indem. } \\
\text { Corp. v. Fleming, } \\
58 \text { P.3d } 965 \text { (Ariz. } \\
\text { Ct. App. 2002). }\end{array}$ & $\begin{array}{l}\text { Arizona follows the broad } \\
\text { cause of action and } \\
\text { balanced six factors. }\end{array}$ \\
\hline Arkansas & $\begin{array}{c}\text { Yes - } \\
\text { generally }\end{array}$ & $\begin{array}{l}\text { Relaxed } \\
\text { Privity }\end{array}$ & $\begin{array}{l}\text { Pettus } v . \\
\text { McDonald, } 36 \\
\text { S.W.3d } 745 \text { (Ark. } \\
\text { 2001); ARK. CODE } \\
\text { ANN. } \$ \text { 16-62-101 } \\
\text { (2001). }\end{array}$ & $\begin{array}{l}\text { Arkansas has two } \\
\text { exceptions to the } \\
\text { requirement of privity: } \\
\text { (1) there is no privity for } \\
\text { fraudulent acts, } \\
\text { omissions, decisions, or } \\
\text { conduct or for } \\
\text { intentional } \\
\text { misrepresentation; and } \\
\text { (2) if the person is the } \\
\text { intended third party } \\
\text { beneficiary. }\end{array}$ \\
\hline
\end{tabular}

196. The excellent assistance of Ms. Eva Hung, J.D., Consultant, Ryan (Houston, Texas) in the preparation of this table is recognized with great appreciation. 


\begin{tabular}{|c|c|c|c|c|}
\hline California & No & $\begin{array}{c}\text { Balancing } \\
\text { Factors }\end{array}$ & $\begin{array}{l}\text { Biakanja v. Irving, } \\
320 \text { P.2d } 16 \text { (Cal. } \\
\text { 1958) (en banc); } \\
\text { Lucas v. Hamm, } \\
364 \text { P.2d } 685 \\
\text { (Cal. 1961) (en } \\
\text { banc). }\end{array}$ & $\begin{array}{l}\text { California was the first } \\
\text { state to have a case } \\
\text { challenge the traditional } \\
\text { strict privity bar against } \\
\text { estate planning attorneys } \\
\text { and established a new } \\
\text { approach by balancing } \\
\text { various factors to } \\
\text { determine a beneficiary's } \\
\text { standing. }\end{array}$ \\
\hline Colorado & No & $\begin{array}{c}\text { Three- } \\
\text { Part Test }\end{array}$ & $\begin{array}{l}\text { Glover v. Southard, } \\
894 \text { P.2d } 21 \\
\text { (Colo. App. } \\
\text { 1994). }\end{array}$ & $\begin{array}{l}\text { Colorado utilizes a three- } \\
\text { part test to strictly limit } \\
\text { attorney's liability to } \\
\text { third parties. }\end{array}$ \\
\hline Connecticut & $\begin{array}{c}\text { Yes - } \\
\text { generally }\end{array}$ & $\begin{array}{l}\text { Relaxed } \\
\text { Privity }\end{array}$ & $\begin{array}{l}\text { Krawczyk v. } \\
\text { Stingle, } 543 \text { A.2d } \\
733 \text { (Conn. } \\
\text { 1988); Robert F. } \\
\text { Phelps, Jr., } \\
\text { Representing Trusts } \\
\text { and Trustees- } \\
\text { Who Is the Client } \\
\text { and Do Notions of } \\
\text { Privity Protect the } \\
\text { Client } \\
\text { Relationship?, } 66 \\
\text { ConN. B.J. } 211 \\
\text { (1992). }\end{array}$ & $\begin{array}{l}\text { Connecticut generally } \\
\text { requires privity, however, } \\
\text { Connecticut has also } \\
\text { recognized an exception } \\
\text { to the privity doctrine on } \\
\text { public policy grounds, if } \\
\text { the plaintiff can establish } \\
\text { he or she is the intended } \\
\text { or foreseeable beneficiary. } \\
\text { Connecticut courts will } \\
\text { also utilize a balancing } \\
\text { test to determine whether } \\
\text { an adequate public policy } \\
\text { exists for the exception to } \\
\text { apply. }\end{array}$ \\
\hline Delaware & Yes & Unclear & $\begin{array}{l}\text { Pinckney v. Tigani, } \\
\text { C.A. No. 02C- } \\
\text { 08129, } 2004 \text { WL } \\
\text { 2827896 (Del. } \\
\text { Super. Ct. Nov. } \\
\text { 30, 2004). }\end{array}$ & $\begin{array}{l}\text { It is unclear whether } \\
\text { Delaware requires privity } \\
\text { in estate planning } \\
\text { malpractice cases. } \\
\text { However, the court in } \\
\text { Pinckney stated, "The } \\
\text { court is unwilling to } \\
\text { abandon privity outright } \\
\text { in Delaware." Pinckney, } \\
\text { 2004 WL 2827896, at } \\
\text { *8. }\end{array}$ \\
\hline
\end{tabular}




\begin{tabular}{|c|c|c|c|c|}
\hline D.C. & $\begin{array}{c}\text { Yes - } \\
\text { generally }\end{array}$ & $\begin{array}{l}\text { Relaxed } \\
\text { Privity }\end{array}$ & $\begin{array}{l}\text { Needham v. } \\
\text { Hamilton, } 459 \\
\text { A.2d } 1060 \text { (D.C. } \\
\text { 1983); Hopkins v. } \\
\text { Akins, } 637 \text { A.2d } \\
\text { 424 (D.C. 1993). }\end{array}$ & $\begin{array}{l}\text { The District of Columbia } \\
\text { generally requires privity, } \\
\text { however, in certain } \\
\text { situations, an exception } \\
\text { to intended third party } \\
\text { beneficiaries may apply. } \\
\text { See Hopkins, } 637 \text { A.2d at } \\
429 \text {. }\end{array}$ \\
\hline Florida & $\begin{array}{c}\text { Yes - } \\
\text { generally }\end{array}$ & $\begin{array}{l}\text { Relaxed } \\
\text { Privity }\end{array}$ & $\begin{array}{l}\text { DeMaris v. Asti, } \\
\text { 426 So. 2d } 1153 \\
\text { (Fla. Dist. Ct. } \\
\text { App. 1983). }\end{array}$ & $\begin{array}{l}\text { Florida utilizes a narrow } \\
\text { exception to the general } \\
\text { privity rule that in order } \\
\text { for the exception to } \\
\text { apply, there must be a } \\
\text { frustrated intent of the } \\
\text { testator. Florida's case } \\
\text { law, combined with } \\
\text { Iowa's, eventually } \\
\text { developed into one of the } \\
\text { three approaches states } \\
\text { now take; the Florida- } \\
\text { Iowa approach. }\end{array}$ \\
\hline Georgia & $\begin{array}{c}\text { Yes - } \\
\text { generally }\end{array}$ & $\begin{array}{l}\text { Relaxed } \\
\text { Privity }\end{array}$ & $\begin{array}{l}\text { Young v. Williams, } \\
645 \text { S.E.2d } 624 \\
\text { (Ga. Ct. App. } \\
\text { 2007); MARY F. } \\
\text { RADFORD, } \\
\text { REDFEARN WILLS } \\
\text { AND } \\
\text { ADMINISTRATION } \\
\text { IN GEORGIA, } \\
\$ 4: 11 \text { (7th ed.). }\end{array}$ & $\begin{array}{l}\text { Up until Young, Georgia } \\
\text { did not have a definitive } \\
\text { position of whether } \\
\text { privity is required. In } \\
\text { Young, Georgia's court of } \\
\text { appeals indicated a } \\
\text { requirement for privity } \\
\text { with a possible, narrow } \\
\text { exception of the } \\
\text { "foreseeable beneficiary" } \\
\text { (i.e., intended third party } \\
\text { beneficiary). }\end{array}$ \\
\hline Hawaii & Silent & $\begin{array}{c}\text { Case-by- } \\
\text { Case }\end{array}$ & $\begin{array}{l}\text { Blair v. Ing, } 21 \\
\text { P.3d } 452 \text { (Haw. } \\
\text { 2001). }\end{array}$ & $\begin{array}{l}\text { Hawaii is generally silent } \\
\text { on whether privity is } \\
\text { required, however, } \\
\text { Hawaii approaches estate } \\
\text { planning malpractice on } \\
\text { a case-by-case basis. For } \\
\text { example, in Blair } v \text {. Ing, } \\
\text { Hawaii adopted the third } \\
\text { party beneficiary } \\
\text { approach because the } \\
\text { broad case approach was } \\
\text { too far reaching. }\end{array}$ \\
\hline
\end{tabular}




\begin{tabular}{|c|c|c|c|c|}
\hline Idaho & $\begin{array}{c}\text { Yes - } \\
\text { generally }\end{array}$ & $\begin{array}{c}\text { Florida- } \\
\text { Iowa }\end{array}$ & $\begin{array}{l}\text { Harrigfeld } v . \\
\text { Hancock, } 364 \text { F.3d } \\
1024 \text { (9th Cir. } \\
\text { 2004). }\end{array}$ & $\begin{array}{l}\text { Idaho generally requires } \\
\text { privity, unless the case } \\
\text { falls into the narrow } \\
\text { exception of the Florida- } \\
\text { Iowa approach (the } \\
\text { frustrated intent of the } \\
\text { testator). }\end{array}$ \\
\hline Illinois & $\begin{array}{c}\text { Yes - } \\
\text { generally }\end{array}$ & $\begin{array}{c}\text { Relaxed } \\
\text { Privity }\end{array}$ & $\begin{array}{l}\text { Pelham v. } \\
\text { Griesheimer, } 440 \\
\text { N.E.2d } 96 \text { (Ill. } \\
\text { 1982). }\end{array}$ & $\begin{array}{l}\text { Illinois generally requires } \\
\text { privity, however, Illinois } \\
\text { will allow recovery if the } \\
\text { case falls within the } \\
\text { intended third party } \\
\text { beneficiary exception. }\end{array}$ \\
\hline Indiana & $\begin{array}{c}\text { Yes - } \\
\text { generally }\end{array}$ & $\begin{array}{c}\text { Relaxed } \\
\text { Privity }\end{array}$ & $\begin{array}{l}\text { Walker v. Lawson, } \\
526 \text { N.E.2d } 968 \\
\text { (Ind. 1988); } \\
\text { ALINE ANDERSON } \\
\text { \& DIANE } \\
\text { KENNEDY, } \\
\text { ANDERSON's } \\
\text { WILLS, TRUSTS, \& } \\
\text { ESTATE } \\
\text { PLANNING, \$ 1:5 } \\
\text { (2014-2015 ed.). }\end{array}$ & $\begin{array}{l}\text { Indiana deviated from } \\
\text { the strict privity concept } \\
\text { and allows for suits by } \\
\text { non-clients, but only if } \\
\text { the non-client is the } \\
\text { intended third party } \\
\text { beneficiary. }\end{array}$ \\
\hline Iowa & $\begin{array}{c}\text { Yes- } \\
\text { generally }\end{array}$ & $\begin{array}{c}\text { Florida- } \\
\text { Iowa }\end{array}$ & $\begin{array}{l}\text { Schreiner } v . \\
\text { Scoville, } 410 \\
\text { N.W.2d 679 } \\
\text { (Iowa 1987). }\end{array}$ & $\begin{array}{l}\text { Iowa allows for non- } \\
\text { clients to sue estate } \\
\text { planning attorneys for } \\
\text { malpractice, but only if } \\
\text { they are the specific, } \\
\text { intended beneficiaries as } \\
\text { expressed in the testator's } \\
\text { testament. Iowa's } \\
\text { exception combined with } \\
\text { Florida's frustrated inten } \\
\text { of the testator created the } \\
\text { Florida-Iowa approach. }\end{array}$ \\
\hline
\end{tabular}




\begin{tabular}{|c|c|c|c|c|}
\hline Kansas & $\begin{array}{c}\text { Yes- } \\
\text { generally }\end{array}$ & $\begin{array}{l}\text { Relaxed } \\
\text { Privity }\end{array}$ & $\begin{array}{l}\text { Pizel v. Zuspann, } \\
795 \text { P.2d } 42 \text { (Kan. } \\
\text { 1990); Jeanes } v . \\
\text { Bank of Am., NA, } \\
295 \text { P.3d } 1045 \\
\text { (Kan. 2013). }\end{array}$ & $\begin{array}{l}\text { Kansas generally requires } \\
\text { privity of contract, } \\
\text { however, Kansas will } \\
\text { allow a legal malpractice } \\
\text { claim against an estate } \\
\text { planning attorney if the } \\
\text { non-client is a } \\
\text { foreseeable, intended } \\
\text { third party beneficiary. }\end{array}$ \\
\hline Kentucky & $\begin{array}{c}\text { No } \\
\text { relevant } \\
\text { case law } \\
\text { located }\end{array}$ & & & \\
\hline Louisiana & $\begin{array}{c}\text { Yes- } \\
\text { generally }\end{array}$ & $\begin{array}{l}\text { Relaxed } \\
\text { Privity }\end{array}$ & $\begin{array}{l}\text { Tuttle v. Schlater } \\
\text { (In re Succession of } \\
\text { Killingsworth), } 292 \\
\text { So. } 2 \mathrm{~d} 536 \text { (La. } \\
\text { 1973). }\end{array}$ & $\begin{array}{l}\text { Louisiana requires privity } \\
\text { but will allow non-client } \\
\text { suits if the non-client is } \\
\text { an intended third party } \\
\text { beneficiary (analogous to } \\
\text { Louisiana's privity laws in } \\
\text { contract). }\end{array}$ \\
\hline Maine & Yes & $\begin{array}{l}\text { Strict } \\
\text { Privity }\end{array}$ & $\begin{array}{l}\text { Nevin v. Union } \\
\text { Trust Co., } 726 \\
\text { A.2d } 694 \text { (Me. } \\
\text { 1999). }\end{array}$ & $\begin{array}{l}\text { Maine follows the strict } \\
\text { privity approach. The } \\
\text { only way to bring a legal } \\
\text { malpractice suit against } \\
\text { an estate planning } \\
\text { attorney is if the plaintiff } \\
\text { is the client or when the } \\
\text { estate is represented by a } \\
\text { personal representative } \\
\text { that stands in the place of } \\
\text { the client. See Nevin, } 726 \\
\text { A.2d at } 701 \text {. }\end{array}$ \\
\hline
\end{tabular}


[Vol. 5:224

\begin{tabular}{|c|c|c|c|c|}
\hline Maryland & $\begin{array}{c}\text { Yes - } \\
\text { generally }\end{array}$ & $\begin{array}{l}\text { Relaxed } \\
\text { Privity }\end{array}$ & $\begin{array}{l}\text { Ferguson v. } \\
\text { Cramer, } 709 \text { A.2d } \\
1279 \text { (Md. 1998); } \\
\text { Noble v. Bruce, } \\
709 \text { A.2d 1264 } \\
\text { (Md. 1998); } \\
\text { Steven I. Platt \& } \\
\text { Jessica Rizer, } \\
\text { Litigating the } \\
\text { Existence, Extent } \\
\text { and Scope of the } \\
\text { Attorney-Client } \\
\text { Relationship, } 40 \\
\text { MD. B.J. 50, } \\
\text { (2007). }\end{array}$ & $\begin{array}{l}\text { Although Maryland will } \\
\text { sometimes allow the } \\
\text { narrow exception of } \\
\text { intended third party } \\
\text { beneficiaries, Maryland } \\
\text { still adheres to the strict } \\
\text { privity approach as } \\
\text { closely as it can. }\end{array}$ \\
\hline Massachusetts & $\begin{array}{c}\text { Yes- } \\
\text { generally }\end{array}$ & $\begin{array}{c}\text { Relaxed } \\
\text { Privity }\end{array}$ & $\begin{array}{l}\text { Williams v. Ely, } \\
668 \text { N.E.2d } 799 \\
\text { (Mass. 1996); } \\
\text { Spinner v. Nutt, } \\
\text { 631 N.E.2d } 542 \\
\text { (Mass. 1994). }\end{array}$ & $\begin{array}{l}\text { Massachusetts generally } \\
\text { requires privity, however, } \\
\text { it allows the intended } \\
\text { third party beneficiary } \\
\text { exception. }\end{array}$ \\
\hline Michigan & $\begin{array}{c}\text { Yes - } \\
\text { generally }\end{array}$ & $\begin{array}{c}\text { Florida- } \\
\text { Iowa }\end{array}$ & $\begin{array}{l}\text { Ginther } v . \\
\text { Zimmerman, } 491 \\
\text { N.W.2d } 282 \\
\text { (Mich. Ct. App. } \\
\text { 1992). }\end{array}$ & $\begin{array}{l}\text { Michigan states that } \\
\text { where the intent of the } \\
\text { testator is not frustrated, } \\
\text { then there is no duty } \\
\text { owed to the party and } \\
\text { will not give rise to a } \\
\text { malpractice action against } \\
\text { the estate planning } \\
\text { attorney. }\end{array}$ \\
\hline
\end{tabular}




\begin{tabular}{|c|c|c|c|c|}
\hline Minnesota & $\begin{array}{c}\text { Yes - } \\
\text { generally }\end{array}$ & $\begin{array}{c}\text { Relaxed } \\
\text { Privity }\end{array}$ & $\begin{array}{l}\text { Marker v. } \\
\text { Greenberg, } 313 \\
\text { N.W.2d } 4 \text { (Minn. } \\
\text { 1981); Admiral } \\
\text { Merch. Motor } \\
\text { Freight, Inc. v. } \\
\text { O'Connor \& } \\
\text { Hannan, } 494 \\
\text { N.W.2d } 261 \\
\text { (Minn. 1992); } \\
\text { McIntosh Cnty. } \\
\text { Bank v. Dorsey \& } \\
\text { Whitney, LLP, } 745 \\
\text { N.W.2d 538 } \\
\text { (Minn. 2008). }\end{array}$ & $\begin{array}{l}\text { It is unclear whether } \\
\text { Minnesota requires a } \\
\text { threshold requirement } \\
\text { that the non-client be an } \\
\text { intended third party } \\
\text { beneficiary before } \\
\text { Minnesota will apply the } \\
\text { balancing factors. In } \\
\text { McIntosh, Minnesota } \\
\text { clarified their privity rule } \\
\text { and stated that the party } \\
\text { must be a direct and } \\
\text { intended beneficiary of } \\
\text { the attorney's services } \\
\text { and then use the } \\
\text { balancing factors to } \\
\text { determine the extent of } \\
\text { the duty owed. McIntosh } \\
\text { Cnty. Bank, } 745 \mathrm{~N} \text {.W. } 2 \mathrm{~d} \\
\text { at } 547 .\end{array}$ \\
\hline Mississippi & $\begin{array}{l}\text { No } \\
\text { relevant } \\
\text { case law } \\
\text { located. }\end{array}$ & & & \\
\hline Missouri & No & $\begin{array}{c}\text { Balancing } \\
\text { Factors }\end{array}$ & $\begin{array}{l}\text { Donahue v. } \\
\text { Shughart, } \\
\text { Thomson, \& } \\
\text { Kilroy, PC, } 900 \\
\text { S.W.2d } 624 \text { (Mo. } \\
\text { 1995). }\end{array}$ & $\begin{array}{l}\text { Missouri balances six } \\
\text { factors to determine } \\
\text { whether attorneys owe a } \\
\text { legal duty to non-clients. }\end{array}$ \\
\hline Montana & Unclear & $\begin{array}{c}\text { Case-by- } \\
\text { Case }\end{array}$ & $\begin{array}{l}\text { Stanley L. \& } \\
\text { Carolyn M. } \\
\text { Watkins Trust v. } \\
\text { Lacosta, } 92 \text { P.3d } \\
620 \text { (Mont. } \\
\text { 2004). }\end{array}$ & $\begin{array}{l}\text { Montana is unclear } \\
\text { whether a duty is owed to } \\
\text { a non-client and has } \\
\text { decided to leave the issue } \\
\text { of standing to bring a } \\
\text { legal malpractice suit } \\
\text { against an estate planning } \\
\text { attorney to the trier of } \\
\text { fact, but has stated that } \\
\text { the balancing approach } \\
\text { could apply. See Stanley } \\
\text { L. \& Carolyn M. Watkins } \\
\text { Trust, } 92 \text { P.3d at } 625 \text {. }\end{array}$ \\
\hline
\end{tabular}




\begin{tabular}{|c|c|c|c|c|}
\hline Nebraska & Yes & $\begin{array}{c}\text { Strict } \\
\text { Privity }\end{array}$ & $\begin{array}{l}\text { Perez v. Stern, } 777 \\
\text { N.W.2d } 545 \\
\text { (Neb. 2010). }\end{array}$ & $\begin{array}{l}\text { Nebraska has } \\
\text { traditionally adhered to } \\
\text { the strict privity } \\
\text { approach, however, in } \\
\text { Perez, Nebraska can be } \\
\text { seen as relaxing strict } \\
\text { privity and stating that an } \\
\text { attorney owed a duty to a } \\
\text { decedent's minor } \\
\text { children. }\end{array}$ \\
\hline Nevada & No & $\begin{array}{c}\text { Balancing } \\
\text { Factors }\end{array}$ & $\begin{array}{l}\text { Charleson v. } \\
\text { Hardesty, 839 P.2d } \\
1303 \text { (Nev. 1992); } \\
\text { Anthony L. } \\
\text { Barney, Preventing } \\
\text { \& Litigating Trust } \\
\text { Disputes (2009). }\end{array}$ & $\begin{array}{l}\text { Nevada has elected to } \\
\text { adopt the balancing } \\
\text { factors test, but maintains } \\
\text { that whether the attorney } \\
\text { assumes a duty of care } \\
\text { towards beneficiaries is } \\
\text { still a question of law. }\end{array}$ \\
\hline $\begin{array}{c}\text { New } \\
\text { Hampshire }\end{array}$ & $\begin{array}{c}\text { Yes - } \\
\text { generally }\end{array}$ & $\begin{array}{l}\text { Relaxed } \\
\text { Privity }\end{array}$ & $\begin{array}{l}\text { Sisson v. } \\
\text { Jankowski, } 809 \\
\text { A.2d } 1265 \text { (N.H. } \\
\text { 2002). }\end{array}$ & $\begin{array}{l}\text { New Hampshire } \\
\text { generally requires strict } \\
\text { privity, however, it has } \\
\text { recognized the exception } \\
\text { of a foreseeable, intended } \\
\text { third party beneficiary } \\
\text { applies in certain } \\
\text { circumstances. }\end{array}$ \\
\hline New Jersey & No & $\begin{array}{l}\text { Four- } \\
\text { Point } \\
\text { Analysis }\end{array}$ & $\begin{array}{l}\text { Rathblott v. Levin, } \\
697 \text { F. Supp. } 817 \\
\text { (D.N.J. 1988); } \\
\text { Joseph C. Mahon, } \\
\text { Intent, Process \&. } \\
\text { Liability in Estate } \\
\text { Planning, 210 N.J. } \\
\text { LAW. 26, (2001). }\end{array}$ & $\begin{array}{l}\text { New Jersey adopts an } \\
\text { approach stating that } \\
\text { privity of contract is not } \\
\text { necessarily required and } \\
\text { instead adopts a four } \\
\text { point analysis to } \\
\text { overcome the privity } \\
\text { requirement. }\end{array}$ \\
\hline New Mexico & No & $\begin{array}{c}\text { Balancing } \\
\text { Factors }\end{array}$ & $\begin{array}{l}\text { Leyba v. Whitley, } \\
907 \text { P.2d } 172 \\
\text { (N.M. 1995). }\end{array}$ & $\begin{array}{l}\text { New Mexico adopts the } \\
\text { balancing factors } \\
\text { approach in determining } \\
\text { whether an attorney owes } \\
\text { a duty to a non-client. }\end{array}$ \\
\hline
\end{tabular}




\begin{tabular}{|c|c|c|c|c|}
\hline New York & Yes & $\begin{array}{c}\text { Strict } \\
\text { Privity }\end{array}$ & $\begin{array}{l}\text { Estate of Schneider } \\
v . \text { Finmann, } 933 \\
\text { N.E.2d } 718 \text { (N.Y. } \\
\text { 2010). }\end{array}$ & $\begin{array}{l}\text { New York still generally } \\
\text { requires privity in legal } \\
\text { malpractice suits against } \\
\text { estate planning attorneys, } \\
\text { however, it has } \\
\text { recognized that a } \\
\text { decedent's estate has } \\
\text { privity against the } \\
\text { decedent's attorney. See } \\
\text { generally Estate of } \\
\text { Schneider, } 933 \text { N.E.2d } \\
718 .\end{array}$ \\
\hline $\begin{array}{l}\text { North } \\
\text { Carolina }\end{array}$ & No & $\begin{array}{c}\text { Balancing } \\
\text { Factors }\end{array}$ & $\begin{array}{l}\text { Jenkins } v . \text { Wheeler, } \\
316 \text { S.E.2d } 354 \\
\text { (N.C. Ct. App. } \\
\text { 1984). }\end{array}$ & $\begin{array}{l}\text { North Carolina adopted } \\
\text { a six-factor balancing test } \\
\text { in an action by a non- } \\
\text { client against an estate } \\
\text { planning attorney. }\end{array}$ \\
\hline $\begin{array}{l}\text { North } \\
\text { Dakota }\end{array}$ & $\begin{array}{l}\text { No } \\
\text { relevant } \\
\text { case law } \\
\text { located. }\end{array}$ & & & \\
\hline Ohio & Yes & $\begin{array}{c}\text { Strict } \\
\text { Privity }\end{array}$ & $\begin{array}{l}\text { Simon v. } \\
\text { Zipperstein, } 512 \\
\text { N.E.2d } 636 \text { (Ohio } \\
\text { 1987). }\end{array}$ & $\begin{array}{l}\text { Ohio is in the minority } \\
\text { of states that still follows } \\
\text { the strict privity } \\
\text { approach. }\end{array}$ \\
\hline Oklahoma & $\begin{array}{c}\text { Yes - } \\
\text { generally }\end{array}$ & $\begin{array}{l}\text { Relaxed } \\
\text { Privity }\end{array}$ & $\begin{array}{l}\text { Leak-Gilbert v. } \\
\text { Fable, } 55 \text { P.3d } \\
\text { 1054 (Okla. } \\
\text { 2002). }\end{array}$ & $\begin{array}{l}\text { Oklahoma recognizes an } \\
\text { exception for intended } \\
\text { third party beneficiaries } \\
\text { to bring a malpractice } \\
\text { action against an estate } \\
\text { planning attorney. }\end{array}$ \\
\hline Oregon & $\begin{array}{c}\text { Yes- } \\
\text { generally }\end{array}$ & $\begin{array}{c}\text { Case-by- } \\
\text { Case }\end{array}$ & $\begin{array}{l}\text { Hale v. Groce, } 744 \\
\text { P.2d } 1289 \text { (Or. } \\
\text { 1987); Roberts v. } \\
\text { Fearey, } 986 \text { P.2d } \\
690 \text { (Or. Ct. App. } \\
\text { 1999). }\end{array}$ & $\begin{array}{l}\text { Oregon has only } \\
\text { extended the attorney's } \\
\text { duty to third parties on a } \\
\text { case-by-case basis. There } \\
\text { are only three cases in } \\
\text { which Oregon has found } \\
\text { a duty was owed to non- } \\
\text { clients - these cases } \\
\text { focused on whether there } \\
\text { is a de facto relationship } \\
\text { between the attorney and } \\
\text { non-client that would } \\
\text { justify an imposition of a } \\
\text { duty. }\end{array}$ \\
\hline
\end{tabular}




\begin{tabular}{|c|c|c|c|c|}
\hline Pennsylvania & $\begin{array}{c}\text { Yes - } \\
\text { generally }\end{array}$ & $\begin{array}{l}\text { Relaxed } \\
\text { Privity }\end{array}$ & $\begin{array}{l}\text { Guy v. Liederbach, } \\
459 \text { A.2d } 744 \text { (Pa. } \\
\text { 1983); RONALD E. } \\
\text { MALLEN \& } \\
\text { JEFFREY M. } \\
\text { SMITH, Legal } \\
\text { Malpractice } \$ 36: 5 \\
\text { (2014 ed.). }\end{array}$ & $\begin{array}{l}\text { Pennsylvania generally } \\
\text { requires privity but } \\
\text { recognizes the intended } \\
\text { third party beneficiary } \\
\text { exception, based on a } \\
\text { contract law theory. } \\
\text { Pennsylvania also follows } \\
\text { the Restatement (Second) } \\
\text { of Contracts, which is } \\
\text { similar to the balancing } \\
\text { factors approach. }\end{array}$ \\
\hline Rhode Island & No & $\begin{array}{c}\text { Balancing } \\
\text { Factors }\end{array}$ & $\begin{array}{l}\text { Am. Kennel Club } \\
\text { Museum of the Dog } \\
\text { v. Edwards \& } \\
\text { Angell, LLP, } 2002 \\
\text { WL } 1803923 \text { (R.I. } \\
\text { 2002) } \\
\text { (unpublished op.). }\end{array}$ & $\begin{array}{l}\text { Rhode Island has adopted } \\
\text { the balancing factors } \\
\text { approach. }\end{array}$ \\
\hline $\begin{array}{c}\text { South } \\
\text { Carolina }\end{array}$ & No & $\begin{array}{l}\text { Relaxed } \\
\text { Privity }\end{array}$ & $\begin{array}{l}\text { Fabian v. Lindsey, } \\
765 \text { S.E.2d } 132 \\
\text { (S.C. 2014); } \\
\text { William P. } \\
\text { LaPiana, The } \\
\text { Privity Barrier } \\
\text { Falls in South } \\
\text { Carolina, EST. } \\
\text { PLAN, Mar. 2015, } \\
\text { at 42. }\end{array}$ & $\begin{array}{l}\text { South Carolina } \\
\text { recognizes a cause of } \\
\text { action, in both tort and } \\
\text { contract, by a third party. } \\
\text { Recovery is limited to } \\
\text { beneficiaries named in } \\
\text { the estate planning } \\
\text { document or otherwise } \\
\text { identified in the } \\
\text { document by their status. }\end{array}$ \\
\hline South Dakota & $\begin{array}{c}\text { Yes - } \\
\text { generally }\end{array}$ & $\begin{array}{l}\text { Relaxed } \\
\text { Privity }\end{array}$ & $\begin{array}{l}\text { Friske v. Hogan, } \\
698 \text { N.W.2d } 526 \\
(\text { S.D. 2005). }\end{array}$ & $\begin{array}{l}\text { South Dakota } \\
\text { traditionally followed the } \\
\text { strict privity approach, } \\
\text { and still generally follows } \\
\text { it. However, South } \\
\text { Dakota has recognized } \\
\text { the intended third party } \\
\text { beneficiary exception. }\end{array}$ \\
\hline Tennessee & $\begin{array}{c}\text { Yes - } \\
\text { generally }\end{array}$ & $\begin{array}{l}\text { Relaxed } \\
\text { Privity }\end{array}$ & $\begin{array}{l}\text { Collins v. Binkley, } \\
750 \text { S.W.2d } 737 \\
\text { (Tenn. 1988). }\end{array}$ & $\begin{array}{l}\text { Tennessee generally } \\
\text { follows the strict privity } \\
\text { approach, but has applied } \\
\text { the intended third party } \\
\text { beneficiary exception to } \\
\text { some cases. }\end{array}$ \\
\hline
\end{tabular}




\begin{tabular}{|c|c|c|c|c|}
\hline Texas & Yes & $\begin{array}{l}\text { Strict } \\
\text { Privity }\end{array}$ & $\begin{array}{l}\text { Belt v. } \\
\text { Oppenheimer, } \\
\text { Blend, Harrison, \& } \\
\text { Tate, Inc., } 192 \\
\text { S.W.3d } 780 \text { (Tex. } \\
\text { 2006). }\end{array}$ & $\begin{array}{l}\text { Texas adheres to the } \\
\text { strict privity approach, } \\
\text { however, in Belt, Texas } \\
\text { recognized that a legal } \\
\text { malpractice suit may be } \\
\text { brought on behalf of the } \\
\text { estate (such as by the } \\
\text { estate's personal } \\
\text { representative). }\end{array}$ \\
\hline Utah & Yes & $\begin{array}{l}\text { Strict } \\
\text { Privity }\end{array}$ & $\begin{array}{l}\text { Atkinson v. IHC } \\
\text { Hosps. Inc., } 798 \\
\text { P.2d } 733 \text { (Utah } \\
\text { 1990). }\end{array}$ & $\begin{array}{l}\text { Utah seems to still follow } \\
\text { the strict privity approach } \\
\text { as it has yet to fully } \\
\text { address the theory of a } \\
\text { non-client recovering for } \\
\text { a legal malpractice claim } \\
\text { against an estate planning } \\
\text { attorney. }\end{array}$ \\
\hline Vermont & $\begin{array}{c}\text { Yes- } \\
\text { generally }\end{array}$ & $\begin{array}{c}\text { Relaxed } \\
\text { Privity }\end{array}$ & $\begin{array}{l}\text { Hedges } v . \\
\text { Durrance, } 834 \\
\text { A.2d } 1 \text { (Vt. 2003). }\end{array}$ & $\begin{array}{l}\text { Vermont does not } \\
\text { directly state the } \\
\text { approach that it follows, } \\
\text { however, it can be } \\
\text { inferred that Vermont } \\
\text { generally follows the } \\
\text { strict privity rule, but } \\
\text { allows the intended third } \\
\text { party beneficiary } \\
\text { exception when } \\
\text { applicable. }\end{array}$ \\
\hline Virginia & $\begin{array}{c}\text { Yes - } \\
\text { generally }\end{array}$ & $\begin{array}{c}\text { Relaxed } \\
\text { Privity }\end{array}$ & $\begin{array}{l}\text { Rutter v. Jones, } \\
\text { Blechman, Woltz, } \\
\text { హ. Kelly, PC, } 568 \\
\text { S.E.2d } 693 \text { (Va. } \\
\text { 2002); Copenhaver } \\
\text { v. Rogers, } 384 \\
\text { S.E.2d } 593 \text { (Va. } \\
\text { 1989). }\end{array}$ & $\begin{array}{l}\text { Virginia generally follows } \\
\text { the strict privity } \\
\text { approach, but will allow a } \\
\text { non-client suit for legal } \\
\text { malpractice against an } \\
\text { estate attorney if the } \\
\text { plaintiff was the intended } \\
\text { beneficiary of the } \\
\text { contract. }\end{array}$ \\
\hline
\end{tabular}




\begin{tabular}{|c|c|c|c|c|}
\hline Washington & No & $\begin{array}{l}\text { Balancing } \\
\text { Factors } \\
\text { and } \\
\text { Relaxed } \\
\text { Privity }\end{array}$ & $\begin{array}{l}\text { Trask v. Butler, } \\
872 \text { P.2d } 1080 \\
\text { (Wash. 1994); } \\
\text { Parks v. Fink, } 293 \\
\text { P.3d 1275 (Wash. } \\
\text { Ct. App. 2013). }\end{array}$ & $\begin{array}{l}\text { Washington combines } \\
\text { the broad cause of action } \\
\text { with the intended third } \\
\text { party beneficiary } \\
\text { exception. The intent to } \\
\text { benefit the plaintiff is the } \\
\text { first and threshold } \\
\text { inquiry in Washington's } \\
\text { multi-factor balancing } \\
\text { test. Trask, } 872 \text { P.2d at } \\
1084 \text {. }\end{array}$ \\
\hline West Virginia & $\begin{array}{c}\text { Yes - } \\
\text { generally }\end{array}$ & $\begin{array}{l}\text { Relaxed } \\
\text { Privity }\end{array}$ & $\begin{array}{l}\text { Calvert v. Scharf, } \\
619 \text { S.E.2d } 197 \\
\text { (W. Va. 2005). }\end{array}$ & $\begin{array}{l}\text { West Virginia follows the } \\
\text { strict privity approach } \\
\text { unless the plaintiff is the } \\
\text { intended third party } \\
\text { beneficiary and the } \\
\text { testator's intent has been } \\
\text { frustrated. }\end{array}$ \\
\hline Wisconsin & No & $\begin{array}{l}\text { Relaxed } \\
\text { Privity }\end{array}$ & $\begin{array}{l}\text { Auric v. Cont'l } \\
\text { Cas. Co., } 331 \\
\text { N.W.2d } 325 \\
\text { (Wis. 1983); } \\
\text { Beauchamp v. } \\
\text { Kemmeter, 625 } \\
\text { N.W.2d } 297 \\
\text { (Wis. Ct. App. } \\
\text { 2000). }\end{array}$ & $\begin{array}{l}\text { Wisconsin applied the } \\
\text { balancing factors in } \\
\text { Auric, moving away from } \\
\text { its traditional strict } \\
\text { privity approach. } \\
\text { However, Wisconsin's } \\
\text { court of appeals narrowed } \\
\text { the balancing factors in } \\
\text { Beauchamp by refusing to } \\
\text { extend Auric and instead } \\
\text { applying the test of } \\
\text { whether the plaintiff was } \\
\text { a named beneficiary. }\end{array}$ \\
\hline Wyoming & No & $\begin{array}{c}\text { Balancing } \\
\text { Factors }\end{array}$ & $\begin{array}{l}\text { In re Estate of } \\
\text { Drwenski, } 83 \text { P.3d } \\
457 \text { (Wyo. 2004). }\end{array}$ & $\begin{array}{l}\text { Wyoming follows the } \\
\text { balancing factors } \\
\text { approach, but with an } \\
\text { emphasis on whether the } \\
\text { plaintiff is an intended } \\
\text { third party beneficiary. }\end{array}$ \\
\hline
\end{tabular}


